Research, part of a Special Feature on Implementing Participatory Water Management: Recent Advances in Theory, Practice and Evaluation

\title{
Participatory Research for Adaptive Water Management in a Transition Country - a Case Study from Uzbekistan
}

\author{
$\underline{\text { Darya Hirsch }}^{1}$, Geraldine Abrami $^{2}, \underline{\text { Raffaele Giordano }}^{3}, \underline{\text { Stefan Liersch }}^{4}$, Nilufar Matin $^{5}$, and \\ $\underline{\text { Maja Schlüter }}^{6}$
}

\begin{abstract}
Participatory research has in recent years become a popular approach for problem-oriented scientific research that aims to tackle complex problems in a real management context. Within the European Union project NeWater, stakeholder processes were initiated in seven case studies to develop approaches for adaptive water management. The Uzbek part of the Amudarya River basin was one of the studied river basins. However, given the current political and cultural context in Uzbekistan, which provides little room for stakeholder participation, it was unclear to what extent participation could be realized there. In this paper, we present an evaluation of the participatory research carried out in the Amudarya case study with respect to (i) the choice and application of different participatory methods and their adaptation to the given political, socioeconomic, and cultural environment, (ii) their usefulness in improving system understanding and developing strategies and measures to improve water management and monitoring, and (iii) their acceptance and suitability for enhancing policy-making processes in the Amudarya River basin context. The main lessons learned from the comparison of the different participatory methods were (1) the stakeholder process provided an opportunity for meetings and discussions among stakeholders from different organizational levels and thus promoted communication between different levels and organizations, and (2) in a context where most stakeholders are not generally involved in policy-making, there is a danger of raising expectations that a research project cannot meet, e.g., of transferring local interests to higher levels. Our experience shows that in order to choose participatory methods and adapt them to the Uzbek cultural and political setting (and most likely this applies to other post-Soviet transition countries as well), four aspects should be taken into account: the time required to prepare and apply the method, good information about the participants and the context in which the method will be applied, knowledge of the local language(s), and careful training of local moderators. While these aspects are relevant to any application of participatory methods, they become even more important in a political and socio-cultural setting such as that found in Uzbekistan. One added value of the activities and a crucial aspect of a participatory research processes was the capacity building of local scientists and practitioners, which facilitates the further application of the methods.
\end{abstract}

Key Words: adaptive water management; Amudarya River basin; participatory methods; stakeholder participation

\section{INTRODUCTION}

Most environmental problems require a holistic approach so that the complexity and interconnectedness of elements can be taken into consideration (Harding 1998, Stringer et al. 2006). With increasing complexity and uncertainty within a system, "professional judgement is needed to supplement the standard techniques" (Harding 1998). The participation of "nonscientific experts" provides insight into social, ethical, and political values that cannot be gained through scientific approaches alone (Middendorf and Busch 1997). Stringer et al. (2006) stress that "by using

\footnotetext{
${ }^{1}$ Institute of Environmental Systems Research, Department of Mathematics and Computer Science, University of Osnabrück and United Nations University, Institute for Environment and Human Security, ${ }^{2}$ Cemagref, ${ }^{3}$ Consiglio Nazionale delle Ricerche-Istituto di Ricerca sulle Acque, ${ }^{4}$ Helmholtz Centre for Environmental Research - UFZ, Umweltforschungszentrum Leipzig, ${ }^{5}$ Stockholm Environment Institute, University of York, ${ }^{6}$ Helmholtz Centre for Environmental Research - UFZ Leipzig \& Leibniz-Institute of Freshwater Ecology and Inland Fisheries
} 
perspectives from a range of sources, a more complete overview is obtained, creating a more robust factual base and reducing uncertainty".

Adaptive management recognizes the importance of multiple perspectives by involving stakeholders in the design and implementation of policies and measures (Pahl-Wostl et al. 2007, Jeffrey et al. 2008). It constitutes a process that offers the possibility to experiment with and compare selected measures and practices. Adaptive management is an organized process of improving management policies and practices by systematic learning from the outcomes of implemented strategies (PahlWostl et al. 2007). The comparison of outcomes, and thus the learning, takes place through evaluation of different views and assumptions about the system (Holling 1978, Walters 1986, Lee 1999). The increasing role of participation in the policy process has manifested itself in several recent European Union (EU) policy directives such as the EU Water Framework Directive, which emphasizes the need for public participation, for example in the development of river basin management plans.

Motivated by the above insights and demands for stakeholder participation, participatory research has in recent years become a popular approach for problem-oriented scientific research that aims to tackle complex problems in a real management context (Fortmann 2008, Laumonier et al. 2008). To some extent, it has even been seen as a panacea to overcome the gap between scientific research and policy-making by involving stakeholders in the research process (Oliver et al. 2005, Hartley and Robertson 2006, Stringer et. al. 2006). While there is no guarantee that participatory research per se will make scientific research more applicable and relevant to policy-making, it can at least integrate diverse knowledge about a particular problem and problem context, which might facilitate a better solution (substantive benefits) (Hanssen et al. 2009), but also, maybe even more importantly, create a better informed and more equitable decision-making process (procedural benefits) (Funtowicz and Ravetz 1993). However, there are also many examples where participation failed to reach its objectives (Santhakumar 2001, Vardanyan and Abrahamyan 2009), may not have been suitable given a certain problem or political context, or even reinforced drawbacks it was supposed to fight (Neef 2009).
The EU project New Approaches to Adaptive Water Management under Uncertainty (NeWater: http://w ww.newater.uos.de) placed a strong emphasis on using participatory research to analyze the water management regimes in seven river basins in Europe, Central Asia, and Africa. The aim of the project was to identify barriers towards and opportunities for changing current practices towards adaptive water management and developing and applying suitable tools to support a transition (Pahl-Wostl et al. 2007). The Uzbek part of the Amudarya River basin was one of NeWater's case studies (Schlüter et al. 2010). However, given the current political and cultural context in Uzbekistan, which allows little room for stakeholder participation in policy-making, there is a question as to whether and how a participatory research process could be realized. To do justice to the political and socio-cultural context in the case study, we chose a careful, step-by-step approach to bringing participatory methods into the research process and assessing their suitability to the given context. The overall aim of the different participatory activities was to integrate different knowledge sources into a better understanding of the management regime and give multiple stakeholders (including researchers) the opportunity to raise their understanding and take part in the identification and discussion of management goals and measures to improve the social, economical, environmental, and political dimensions of water governance at various levels.

Within the participatory research processes, several different participatory methods were applied. The aim of this paper is to (1) discuss the choice and adaptation of different participatory methods to the Uzbek socio-cultural context and their acceptance by stakeholders; (2) assess the effectiveness of the application in terms of an increase in system understanding, the development of strategies and measures to improve water management and monitoring, and the involvement of stakeholders in system dynamics appraisal; and 3) discuss the potential of participatory methods to enhance the policy-making process in a transitional and authoritarian country such as Uzbekistan.

In this paper, we give a short overview of the cultural, political, socioeconomic, and ecological context of participatory research in Uzbekistan, describe the framework and methodology used for the evaluation and comparison of the methods used 
in the Amudarya case study, and present and discuss the results. We then conclude with a discussion of the suitability of various participatory research methods in the given socio-political context, and present ideas on how involvement of stakeholders might enhance water management in the Amudarya case study.

\section{THE CONTEXT FOR PARTICIPATORY RESEARCH IN THE AMUDARYA CASE STUDY}

The economies of the Central Asian countries and the livelihoods of their human populations as well as riverine ecosystems are dependent on the Amudarya and Syrdarya Rivers, which together account for nearly $90 \%$ of the region's surface water resources (Jalling 2006, Sokolov 2008). With the construction of huge water diversion and irrigation schemes by the Soviets, from the 1950s onwards water usage rapidly increased, leading to the full utilization of river flows by the 1980s. The massive overuse of water resources resulted in the loss of the southern part of the Aral Sea, severe soil salinization in agricultural areas, and loss of wetlands in the Amudarya River delta. The environmental degradation causes enormous damage to agricultural production every year (MAWR 2003, Shirokova and Morozov 2006), is responsible for the loss of wetland ecosystem resources such as fish and reeds, which play a major role in the livelihoods of the local populations, and impacts on human health (ERM 2003). Moreover, due to soil salinization, currently up to $40 \%$ of the water resources have to be used to leach the salt from the fields (MSF 2003, Schlüter et al. 2007).

Uzbekistan is the largest (in population) and regionally the most influential of the five former Soviet Union states in Central Asia. After independence the government chose to take a slow approach to transforming the nation's economy, with emphasis on maintaining state regulation and a slow transition to a market economy without revolutionary "jumps" or "shock therapy" (Akhmedov 2006). More than 15 years after independence Uzbekistan is struggling with an overall deteriorating socioeconomic situation (CER and UNDP 2005).

Politically, Uzbekistan is characterized by an authoritarian post-Soviet regime (Adams 1999, March 2003a, 2003b, Veldwish 2008). Water management, to a large extent, follows a top-down, technocratic management approach (Veldwish 2008), which is characterized, for example, by the dominance of group or corporate interests in the process of water allocation (Dukhovny 2005). Within Uzbekistan, the state exerts strong control and retains a strong role in policy-making. A civil society is only very slowly developing (Spoor 2004, Veldwish 2008). Spoor (2004) stresses that Uzbekistan (and Turkmenistan) "see civil society development more as a threat than a necessity for rural recovery and development", and that "civil society in these countries is most likely to evolve from organizations that were either part of the state or connected to it" (e.g., collective farms). During the Soviet period and the first years of independence, there were no organizations that could deal with water-ecological issues at the stakeholder level and involve interested parties in the process. With the introduction of Integrated Water Resource Management (IWRM) to the region by state officials, who learned from international experience and by international donor projects, the issue of stakeholder participation became more prominent, although it often remained at the level of lip service (Sehring 2009).

However, there is a trend and a need for the state to involve users, for example farmers, in water allocation planning and management, particularly following the transformation of state farms into smaller scale units in 2003 (Yalcin and Mollinga 2007). As part of this reform, several communitybased management structures, such as water user associations (WUAs), were introduced. WUAs were conceived as a "bridge" between the state irrigation management organizations and semiprivate water users. However, most changes towards more participation by water users exist only on paper, and current institutions such as WUAs remain strongly controlled and influenced by the state. Genuine stakeholder participation in water management and in the lower levels of the hierarchy of the water economy has not been developed, with the exception of certain pilot irrigation systems where implementation of IWRM principles has been started (e.g., the IWRM-Ferghana project supported by the Swiss Agency for Development and Cooperation [SDC] and the International Water Management Institute [IWMI]) (UNEP 2005). An interesting insight on the introduction of WUAs in Central Asia can be found in Sehring (2009), who describes how strong path dependencies (communist and patronizing heritage) hinder the development 
of effective deliberative governance models and instead lead to hybrid institutional forms where rules that remained from communist heritage and the patronizing system are mixed with carefully selected new WUA formal rules.

On the other hand, it is becoming increasingly evident that the lack of stakeholder participation in land and water management is one of the limiting factors for agricultural production and sustainable water resources management in the region (Mirzaev and Saidov 2008). The introduction of participation in the form of an experimental research process might then be an opportunity to reveal pragmatic benefits of stakeholders' involvement. It has to be done carefully, together with an in-depth institutional and political analysis.

\section{Participatory research in Uzbekistan}

In the wake of massive international support to the countries of Central Asia after independence in 1991, several donor and research projects have introduced participatory methods, mainly for deliberation and assessment but also to facilitate mutual learning between the participating stakeholders and researchers (e.g., IWMI 2002, Thurman 2002, Zavgorodnyaya 2002, Wall 2006, Kan et al. 2008). Table A1 in the Appendix gives a summary of participatory methods that were applied during the last decade (2000-2010)in Uzbekistan.

The methods most frequently used so far have been different kinds of participatory rural appraisal and questionnaire surveys which engaged stakeholders in the lowest level of water management: i.e., farmers. The aim of using participatory rural appraisal and questionnaires was to assess needs, context, and impact of economic and/or other changes at the community level and to improve system understanding. The approaches did not aim at a vertical integration of different organizational levels of water management. Also, the studies listed in Table A1 do not reflect on the effect of the application of those methods and the participatory research, or the purpose and benefits or problems associated with participation.

\section{THE PARTICIPATORY ACTIVITIES AND THE EVALUATION FRAMEWORK}

Given the current socioeconomic and ecological situation in Uzbekistan, our research aimed to identify opportunities for and barriers to changing current water management practices towards more equitable ones, both substantially (equitable sharing of water resources) and procedurally (equitable access to decision-making). The research process was built as much as possible in collaboration with local scientists and stakeholders in a reflexive and participatory way. Local scientists played a particularly important role in adjusting our processes to the local circumstances. The initial legitimacy in implementing participatory activities was given by a stakeholder consultation at the beginning of the project, which involved approximately 60 stakeholders at levels from the transboundary to the local. This consultation ranked the need for an assessment of participatory methods that would be suitable for the Uzbek political and cultural context as a priority research issue. This legitimacy was reinforced by the expressed will of local scientists from Uzbek water management agencies to learn about participatory methods.

\section{Organization of the participatory research process}

The following four key issues were selected as focal topics for the participatory research process based on the participatory assessment of research needs in the river basin and thematic and stakeholder analyses carried out by the NeWater team (Schlüter et al. 2010): (1) development of approaches for local water and soil quality management; (2) methods for adaptation to high variability in river flow and to extreme events; (3) implications of the social dimension of water management: poverty, gender, and health; and (4) improving the provision of wetland ecosystem services by incorporating ecological water requirements of the Amudarya River delta into water management. The importance of transboundary issues for water management on the national to local levels was repeatedly mentioned by the stakeholders. Stakeholders from the upstream country Tajikistan and the downstream neighbour Turkmenistan participated in several of the scoping workshops for the identification of the most pressing issues in the river basin. As a result, one research activity focused exclusively on transboundary information management and donor involvement on the basin scale (Kranz et al. 2005, 2007, 2008). However, transboundary cooperation was not selected as a specific focus for stakeholder activities because of the sensitivity of the issue.

Stakeholder and research activities that addressed those issues within the framework of adaptive management were conducted by several teams of 
European and Uzbek scientists who used participatory and standard scientific approaches (Schlüter et al. 2007, Giordano et al. 2008, Abrami and Schlüter 2009). The four issues and the associated participatory research activities are listed in Table 1. The table also details the methodology used by each activity, its objectives, and the organization of each activity.

The participatory research process took place from 2005 to 2008 . It consisted of eight main workshops that focused on adaptive management in the Amudarya River basin and which were attended by 30-40 stakeholders each, and 10 smaller workshops that focused on selected topics. The main workshops brought together people from different management levels, interest groups, sectors, and backgrounds (Table A2 in the Appendix).

Participants for all workshops were selected by the case study team (European and Uzbek scientists) according to their affiliation with management levels, the focus of the activity, and the participants' roles in water management or water use. We aimed for a fairly even distribution of the different roles decision-maker, implementer, monitor, affected, influencing and interested party, researcher, and nongovernmental organization (NGO) - to elicit a wide range of stakeholder perspectives and preferences and to promote horizontal and vertical cooperation between stakeholders and experts. For example, stakeholders were invited from different levels of an organization and its subsidiary bodies (e.g., the Ministry of Agriculture and Water Management, plus its province and district departments), or from organizations that currently show little interaction with one another (e.g., water management organizations, nature protection organizations, water users, fishermen) but which were relevant for a particular topic.

\section{Description of the participatory methods}

The following is a short description of the different participatory methods that were applied in the seven activities. More details about the different methods are provided in Table 2 .

Nominal Group Technique (NGT) is an alternative to open brainstorming. In a group, people are asked to brainstorm individually on a certain issue and write down their ideas on cards, which are collected and posted on a flip chart. The cards are then rated by each participant. In this way, NGT helps the group gather a range of ideas and prioritize them.

Community-based Research (CBR) takes place in community settings and involves community members in the design and implementation of research projects. Such activities should demonstrate respect for the contributions that are made by community partners as well as for the principle of "doing no harm" to the communities involved.

Cognitive Mapping (CM) is the construction of visual representations of interrelated concepts. Causal modeling (Vennix 1996), one of the many forms of cognitive mapping, is used to build a model of important factors related to a specific question. The exercise is typically done individually (with a supervisor). The starting point is a central issue (goal) around which the participant develops first and second order causes, feedback loops, and strategic points of intervention.

Cognitive maps can be preparatory to Group Model Building (GMB), an interview method in which a group of people collectively creates a single cognitive map, which generally requires skilled facilitation. Application of both methods helps people move away from their "normal" way of thinking by means of visualization (e.g., CM) and synthesized representations of reality (e.g., GMB).

The Strategic Choice Approach (SCA) is a practical set of tools for communication and collaborative decision-making that is especially suited to situations in which uncertainties exist and are recognized. The approach challenges the four familiar management and planning norms of linearity, objectivity, certainty, and comprehensiveness. Instead, a case was made for learning to work with four alternative precepts: those of cyclicity, subjectivity, uncertainty, and selectivity (Friend and Hickling 1997). The approach also provides an interactive forum between people with different backgrounds and skills who are "attempting to address tough decisions under uncertainty while working together under insistent yet continually shifting action pressures" (Friend and Hickling 1997).

In the stream of participative modeling, Roleplaying Games (RPG), as practised by the ComMod group researchers (Companion Modelling: http://co rmas.cirad.fr/ComMod/en/index.htm), are interactive simulations of the uses and dynamics of a 
Table 1. Activities in the Amudarya case study and participative methods applied.

\begin{tabular}{|c|c|c|c|c|c|c|c|}
\hline Issue & Extreme events & $\begin{array}{l}\text { Wetland ecosystem } \\
\text { services }\end{array}$ & Social dimension & Social dimension & $\begin{array}{l}\text { Community-based } \\
\text { water and wetland } \\
\text { management }\end{array}$ & $\begin{array}{l}\text { Soil quality } \\
\text { management }\end{array}$ & $\begin{array}{l}\text { Participative evaluation } \\
\text { of project findings }\end{array}$ \\
\hline Activity & $\begin{array}{l}\text { Assessment of } \\
\text { institutional barriers } \\
\text { for managing } \\
\text { droughts }\end{array}$ & $\begin{array}{l}\text { Identification of } \\
\text { indicators for } \\
\text { monitoring } \\
\text { environmental flows }\end{array}$ & $\begin{array}{l}\text { Community-based } \\
\text { research on social } \\
\text { aspects of water } \\
\text { management }\end{array}$ & $\begin{array}{l}\text { Community-based } \\
\text { research-validation }\end{array}$ & $\begin{array}{l}\text { Community-based } \\
\text { research-Gaming } \\
\text { sessions }\end{array}$ & $\begin{array}{l}\text { Participative design of } \\
\text { monitoring system }\end{array}$ & $\begin{array}{l}\text { Participative evaluation of } \\
\text { project findings }\end{array}$ \\
\hline Method applied & $\begin{array}{l}\text { Nominal group } \\
\text { technique }\end{array}$ & $\begin{array}{l}\text { Cognitive mapping and } \\
\text { group model building }\end{array}$ & $\begin{array}{l}\text { Public communication } \\
\text { meetings and focus } \\
\text { groups }\end{array}$ & $\begin{array}{l}\text { Strategic choice } \\
\text { approach }\end{array}$ & $\begin{array}{l}\text { Role-playing game } \\
\text { (companion modeling) }\end{array}$ & Cognitive mapping & $\begin{array}{l}\text { Cognitive mapping and } \\
\text { group model building }\end{array}$ \\
\hline Objective & $\begin{array}{l}\text { Priority setting for } \\
\text { policies dealing with } \\
\text { extreme events, } \\
\text { knowledge exchange } \\
\text { among participants; } \\
\text { knowledge elicitation } \\
\text { Integration of } \\
\text { knowledge of } \\
\text { specialists from } \\
\text { different management } \\
\text { levels and } \\
\text { identification of } \\
\text { feasible measures to } \\
\text { address complex issue } \\
\text { of droughts }\end{array}$ & $\begin{array}{l}\text { Assessment of } \\
\text { environmental flow } \\
\text { requirements of deltaic } \\
\text { ecosystems; } \\
\text { Identification and } \\
\text { selection of ecological } \\
\text { and social indicators for } \\
\text { monitoring of wetland } \\
\text { vulnerability }\end{array}$ & $\begin{array}{l}\text { Capturing different } \\
\text { viewpoints on water } \\
\text { management and } \\
\text { livelihood strategies } \\
\text { from among the local } \\
\text { water users and } \\
\text { managers in a } \\
\text { community } \\
\text { Capturing diversity } \\
\text { based on the nature of } \\
\text { livelihoods; landholding } \\
\text { status; types of crops } \\
\text { produced; location of } \\
\text { the lakes or farms along } \\
\text { the irrigation canals; } \\
\text { gender status of the } \\
\text { households; migration } \\
\text { status, and ethnicity }\end{array}$ & 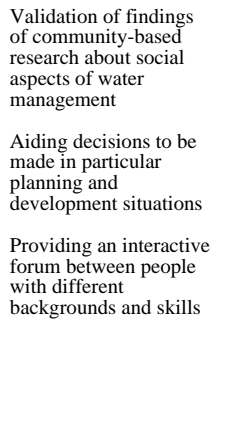 & $\begin{array}{l}\text { Building of a shared } \\
\text { understanding of factors } \\
\text { that shape vulnerability } \\
\text { and responses options to } \\
\text { low water events } \\
\text { Improving } \\
\text { understanding of } \\
\text { behaviors of resource } \\
\text { users and management } \\
\text { rules } \\
\text { Testing the use of role- } \\
\text { playing games in the } \\
\text { Uzbek context } \\
\text { Making participants } \\
\text { aware of impacts of } \\
\text { their actions on the } \\
\text { system }\end{array}$ & $\begin{array}{l}\text { Identification of } \\
\text { indicators for } \\
\text { community -based } \\
\text { monitoring of soil } \\
\text { salinity and wetland } \\
\text { ecosystems } \\
\text { Enhancement of the } \\
\text { usability of local } \\
\text { knowledge to support } \\
\text { environmental } \\
\text { monitoring for adaptive } \\
\text { management }\end{array}$ & $\begin{array}{l}\text { Feedback on research } \\
\text { findings } \\
\text { Discussing joint } \\
\text { understanding of the } \\
\text { current regime } \\
\text { Integration of the } \\
\text { knowledge of specialists } \\
\text { from different management } \\
\text { levels and identification of } \\
\text { feasible measures for } \\
\text { selected issues } \\
\text { Elicitation of stakeholders' } \\
\text { knowledge on status quo } \\
\text { and potential measures }\end{array}$ \\
\hline $\begin{array}{l}\text { Organization of } \\
\text { activity } \\
\text { (Method/ } \\
\text { Activity at each } \\
\text { step and number } \\
\text { of people } \\
\text { involved) }\end{array}$ & $\begin{array}{l}\text { 1. Identifying water } \\
\text { shortage problems } \\
\text { and potential } \\
\text { solutions } \\
\text { (individually) } \\
\text { 2. "Round robin"- } \\
\text { presentation of results } \\
\text { of 1. (collectively) } \\
\text { 3. Clarification } \\
\text { questions from other } \\
\text { participants } \\
\text { (collectively) } \\
4 \text {. Voting on most } \\
\text { important issues } \\
\text { (individually) } \\
\text { Final discussion } \\
\text { (collectively) }\end{array}$ & $\begin{array}{l}\text { 1. Cognitive mapping } \\
\text { (individually) } \\
\text { 2. Group-model } \\
\text { building } \\
\text { (collectively) } \\
\text { 3. Assessment of } \\
\text { feasible changes and } \\
\text { measures } \\
\text { (collectively) } \\
\text { 4. Presentation of } \\
\text { models } \\
\text { (collectively) } \\
\text { Final discussion } \\
\text { (collectively) }\end{array}$ & $\begin{array}{l}\text { 1. Public communi- } \\
\text { cation meetings } \\
\text { (collectively) } \\
\text { 2. Focus groups } \\
\text { (collectively) } \\
\text { 3. Dialogue with co- } \\
\text { researchers } \\
\text { (individually) } \\
\text { Validation workshops } \\
\text { (see next column) } \\
\text { (collectively) }\end{array}$ & $\begin{array}{l}\text { 1. Choosing focus areas } \\
\text { for problem solving } \\
\text { (collectively) } \\
\text { 2. Developing options } \\
\text { for what can be done } \\
\text { realistically, particularly } \\
\text { in view of uncertainties } \\
\text { (collectively) } \\
\text { 3. Identifying actions } \\
\text { for solving the problems } \\
\text { (collectively) } \\
\text { Identifying actors that } \\
\text { can deliver } \\
\text { (collectively) }\end{array}$ & $\begin{array}{l}\text { 1. Explaining objectives } \\
\text { and rules of the game } \\
\text { (collectively) } \\
\text { 2. Roles distribution } \\
\text { (collectively) } \\
\text { 3. Test round } \\
\text { (individually/ } \\
\text { collectively) } \\
\text { 4. Operational } \\
\text { debriefing } \\
\text { (collectively) } \\
\text { 5. Game execution } \\
\text { (individually/ } \\
\text { collectively) } \\
\text { 6. Discussion and } \\
\text { debriefing } \\
\text { (collectively) } \\
\\
\text { Debriefing of } \\
\text { moderators } \\
\text { (individually) }\end{array}$ & $\begin{array}{l}\text { 1. Semi-structured } \\
\text { interviews with local } \\
\text { community members } \\
\text { (individually) } \\
\text { 2. Group session with } \\
\text { local community } \\
\text { (collectively)Semi- } \\
\text { structured interviews } \\
\text { with scientists (experts) } \\
\text { (individually) } \\
\text { Group discussion with } \\
\text { scientists } \\
\text { (collectively) }\end{array}$ & $\begin{array}{l}\text { 1. Cognitive mapping } \\
\text { (individually) } \\
\text { 2. Group-model building } \\
\text { (collectively) } \\
\text { 3. Assessment of feasible } \\
\text { changes and measures } \\
\text { (collectively) } \\
\text { 4. Presentation of models } \\
\text { (collectively) } \\
\text { Final discussion } \\
\text { (collectively) }\end{array}$ \\
\hline
\end{tabular}

resource within a community. In an RPG session, each participant plays the role of a user or manager of the resource. Settings and rules of an RPG consist of a simplified version of the social-ecological system surrounding the resource. After the game, a debriefing session is held to qualify or disqualify events that happened during the game in relation to reality, and to (collectively) acknowledge collective learning (Barreteau et al. 2007). The RPG experiments can be coupled with the development of an Agent-based Model to question key constraints and parameters that seem to impact adaptive water management.

\section{The evaluation framework and data}

The reflexivity of the research process relies partly on the building of an evaluation framework. We adapted and extended Rowe and Frewer's (2000) framework, which seeks to evaluate stakeholder participation in policy design or implementation. In our case, where policies allow very limited scope for action by individual or local initiatives in water resources management, we prefer to speak of stakeholder involvement in system dynamics appraisal. We nevertheless decided to use Rowe and Frewer's (2000) catalogue of questions as a framework for the analysis because they address important aspects of any stakeholder process. 
Table 2. General description of the different participative methods used in the Amudarya Case Study

\section{Methodology}

Good for

Process of application

Limitations

\section{Nominal group technique}

- Ensuring equal participation of each member of the team

- Building commitment

- Making the team's consensus visible

Introduction and explanation done by facilitator

Silent generation of ideas by participants (10 minutes)

Sharing ideas (without debates) by participants, recorded by facilitator (round robin process; $15-30$ minutes)

Group discussion (30-45 minutes)

Voting and ranking

\section{Community based research (FGDs)}

Community-based research often produces unanticipated and far reaching ancillary results, including new social relationships and trust, as well as heightened social efficacy ${ }^{\ddagger}$
Choosing the question which build relationship with the stakeholders in order to understand how the research will fit in with their social change goals

Designing the method for the considerations of how involved the community group wants to be in the actual research

Collecting the data for the ability to build and skills and relationships by collecting data together and from each other

\section{Analyzing the data}

Reporting the results could be an oral report at a community meeting or testimony at city council or a glossy brochure ${ }^{\S}$

\section{Strategic Choice Approach}

- Aiding decisions to be made in particular planning and development situations - Providing an interactive forum between people with different backgrounds and skills
Shaping the problem areas

Designing what can be done, looking at possibilities and drawbacks.

Comparing various ideas, evaluating the best possible way forward

Choosing the best ideas for solving the problems acknowledging any uncertainties
Opinions may not converge in the voting process

Cross-fertilization of ideas may be constrained The process may appear to be too mechanical ${ }^{\dagger}$
Difficulties with respect to funding, and establishing continuity between community contacts and institutions and the research team. 
Role playing game (as in companion modeling)

- Embedding participants in a simulation experiment; making local knowledge more valuable, favouring communication and creativity

- Enhancing participants understanding of their mutual interactions and system - Providing scientists with opportunity to better understand behaviours and interactions ${ }^{\prime}$

\section{Cognitive mapping}

Collection, structure and integration of different understandings of the environmental system to be managed and of the information needed for the management process ${ }^{\dagger \dagger}$

\author{
Consideration of overall question/goal by \\ facilitator \\ Writting down, on individual cards, causes \\ that are important to a participant and that are \\ directly linked to the question (1st order cause) \\ Writting down causes that influence those \\ already in the model, i.e. behind them (2nd \\ order causes) \\ Identification of the relationships \\ Giving a name to the model and signing it
}

Building a conceptual model focusing on the question at stake dynamics; spatial characteristics transferred on become game rules; resource use and management are left to players with different

RPG operationalisation : test and calibration,

RPG sessions : game and debriefings reshaping, model evolution ${ }^{\text {I }}$

\section{Group model building}

- Team learning

- Consensus formation

- Improved acceptance of management decision
Consideration of overall question/goal by facilitator

Nomination of a referee

One by one presents the one card from the own cognitive maps and adds it to the model Discussion about the meaning of each card and its position

Grouping cards by facilitator

Possible definition for potential measures and relevant actors
"Good knowledge of local context and power relationships is needed to decipher game events, conduct efficient de-briefing, and take care that the process is not used to reinforce existing power in-equalities High demands for well organized debriefing, language barriers Needs at least 3 people to organize, well trained local facilitators, at least $1 / 2$ day

The cognitive maps are not self-explaining, good records of presentations by the owners are essential.
Limited representational capabilities of graph-based models. They cannot always represent consistently dynamic relationships between variables. For example, relationships that might change as a result of feedback effects or a tipping point being reached, cannot be easily represented using these static formats. See also Vennix (1996) for other problems.

$\dagger$ Sample, 1984

\$ Sclove, R. et al., 1998.

§ Stoecker, R. 2004.

I Barreteau et al., 2007.

II Bousquet et al.., 2002

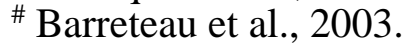

$\dagger$ SEECON. 2007.

\# Hare, M.2007. 
We adapted Rowe and Frewer's (2000) framework to our needs, for example by replacing the criterion "Structured decision-making" with the criterion "System understanding", which was considered more relevant for the given setting. From the original set of criteria developed by Rowe and Frewer (2000), we selected the acceptance criteria "representativeness of participants", "independence of participants", "early involvement" and "transparency", and the process criteria "resource accessibility", "task definition", "system understanding", and "cost effectiveness" as suitable indicators for our evaluation of the seven participatory research activities in the Uzbek case study.

In order to introduce a semi-quantitative measure for each criterion, we defined each with the aid of a number of questions that were answered by each organizer of a participatory activity. The detailed scoring process is shown in Table A3 in the Appendix. Next to the evaluation of the process itself, we assessed its effectiveness in terms of enhancing system understanding, as well as the appreciation of the methods by participants.

Table 3 summarizes the data that were collected during the participatory activities for feeding the evaluation. Observations during the meeting, minutes of the meeting, analyses of the results, as well as oral feedback from the participants were the most common sources for evaluating participation and appreciation of the methods by involved stakeholders in all activities carried out in the Amudarya case study. Debriefing of facilitators was also used quite frequently in cases where the scientists who organized the event did not speak the local language, and thus the event was conducted by a local facilitator. We found some reluctance on the part of stakeholders to evaluate the activities, which might be attributed to the cultural setting in Uzbekistan where stakeholders are generally not accustomed to discussing and voicing their opinions after meetings and consider it an unimportant aspect of an activity. However, in most cases, there were also critical individuals who openly voiced their opinions and approval or disapproval of the workshop procedure or content.

Requests for written feedback directly after the event were mostly met; requests for feedback later on received a very low level of return. Electronic feedback was difficult because of limited or difficult email access and the lack of an "email culture".
The criteria used for the evaluation are defined as follows:

\section{Acceptance criteria}

"Representativeness" measured the degree to which all stakeholders who were relevant to the issue under consideration were invited and took part in the activity and were able to present their position and opinions. We also evaluated representativeness in terms of the equal involvement of participating stakeholders who had different roles, such as decision-maker, implementer, monitor, affected, influencing and interested party, researcher, or NGO. To ensure this, the organizers needed good information about the participants, which was provided mainly by local scientific partners and stakeholders. The responses in the category "representativeness", summarized in Table A3 in the Appendix, show that in several cases not all invited stakeholder attended the event.

The "independence" criterion reflected whether participants were independent in their opinions and articulation - i.e., they were not influenced by the moderators or other participants nor withheld their real opinions in order to satisfy either officials in attendance or researchers who were conducting the survey. Independence indicates the extent to which participants represent the reality of the issue at stake (Witteveen and Enserink 2007).

The criterion "early involvement" measured whether participations were already involved in earlier project activities from the beginning of the project or later on, and whether they were aware of the goals and activities of the project.

"Transparency" refers to the extent to which stakeholders were informed about the use of the gathered data. It also measured whether participants actively participated in the evaluation of the data and understood how the information they provided would be processed/analyzed.

\section{Process criteria}

The criterion "Resource accessibility" evaluated the conditions of and needs for the participatory activity, e.g., whether the demand for equipment and time was high. The criterion was also used to assess the conditions for effective communication, such as whether there was a professional facilitator or whether there were language barriers. 
Table 3. Data used for evaluation of participative activity.

\begin{tabular}{|c|c|c|c|c|c|c|c|}
\hline Activity & $\begin{array}{l}\text { Assessment of } \\
\text { institutional } \\
\text { barriers for } \\
\text { change }\end{array}$ & $\begin{array}{c}\text { Expert } \\
\text { workshop on } \\
\text { environmental } \\
\text { flows }\end{array}$ & $\begin{array}{c}\text { Community- } \\
\text { based research } \\
\text { on social } \\
\text { aspects (focus } \\
\text { group } \\
\text { discussions) }\end{array}$ & $\begin{array}{l}\text { Community- } \\
\text { based } \\
\text { research- } \\
\text { validation }\end{array}$ & $\begin{array}{l}\text { Community- } \\
\text { based } \\
\text { research- } \\
\text { gaming } \\
\text { sessions }\end{array}$ & $\begin{array}{l}\text { Participative } \\
\text { design of } \\
\text { monitoring } \\
\text { system }\end{array}$ & $\begin{array}{c}\text { Participative } \\
\text { evaluation of } \\
\text { project } \\
\text { findings }\end{array}$ \\
\hline $\begin{array}{l}\text { Observations } \\
\text { during the } \\
\text { meeting }\end{array}$ & Yes & Yes & Yes & Yes & Yes & Yes & Yes \\
\hline $\begin{array}{l}\text { Minutes of } \\
\text { the meeting }\end{array}$ & Yes & Yes & Yes & Yes & $\begin{array}{c}\text { No } \\
\text { (no } \\
\text { transcript) }\end{array}$ & No & Yes \\
\hline $\begin{array}{l}\text { Debriefing } \\
\text { of facilitators }\end{array}$ & No & Yes & No & Yes & Yes & No & No \\
\hline $\begin{array}{l}\text { Informal } \\
\text { interviews of } \\
\text { some } \\
\text { participants } \\
\text { after the } \\
\text { meeting }\end{array}$ & Yes & No & No & No & $\begin{array}{l}\text { Yes ( } 3-4 \\
\text { weeks later } \\
\text { by a } \\
\text { researcher } \\
\text { who had not } \\
\text { attended the } \\
\text { sessions) }\end{array}$ & No & No \\
\hline $\begin{array}{l}\text { Oral } \\
\text { feedback } \\
\text { from } \\
\text { participants }\end{array}$ & Yes & Yes & No & Yes & Yes & No & Yes \\
\hline $\begin{array}{l}\text { Analysis of } \\
\text { the results }\end{array}$ & Yes & Yes & Yes & Yes & Yes & Yes & Yes \\
\hline $\begin{array}{l}\text { Debates } \\
\text { among local } \\
\text { stakeholders } \\
\text { and } \\
\text { researchers }\end{array}$ & No & Yes & No & No & No & Yes & No \\
\hline $\begin{array}{l}\text { Written } \\
\text { feedback } \\
\text { from the } \\
\text { participants }\end{array}$ & Yes & No & No & No & No & Yes & No \\
\hline
\end{tabular}

The criterion "Task definition" refers to the extent to which the purpose of the participatory activity was announced, the connection to previous NeWater activities was made clear, and the overall focus of the task/activity was well explained.

"System understanding" measured whether the activity increased the system understanding of the participants with the help of the applied methods.
"Cost effectiveness": A discussion of the cost effectiveness of participatory "methods" is difficult for a number of reasons (Martin and Sherington 1997): participatory "methods" are context sensitive, the resources needed for collaborative participatory work are often underestimated, and the methodologies for monitoring and evaluation have often been weak. For our evaluation of the appreciation of methods by participants, we 
considered under cost-effectiveness the operationalization of the participatory activity, the amount of preparation beforehand, and the motivation of participants to participate in the activity (in most cases, this criterion was recorded in the evaluation sheets directly after the activity).

\section{EX POST ANALYSIS OF THE PARTICIPATORY ACTIVITIES}

Despite the diversity of the participatory methods used, Table 1 illustrates some similarities between the applications' objectives, i.e., achieving a more holistic system understanding among the participants (scientists and stakeholders). All methods also enabled the participants to assess the current situation with respect to the issues addressed (often beyond water use for irrigation) and define potential measures (short, medium, and long term) for improving current water management and its monitoring. Through the participatory research, stakeholders were involved in a system dynamics appraisal of natural resource management and were given the opportunity to articulate their needs and concerns.

\section{Choice and application of the methods}

The choice of the participatory methods used in the different activities of the case study was determined by three factors: the demand from the NeWater project structure (stakeholders' participation was a priority of the NeWater project); the demand from the local stakeholders; and the literature and previous experience of the researchers. A major criterion for choosing a specific method was also the stage of the participation process. At the beginning of the project, knowledge elicitation tools such as NGT or mapping techniques were helpful in exploring the prevalent perspectives about a certain issue or for structuring purposes. Stakeholder communication meetings were used in the early stages of the community-based research to gather individual views on problems and solutions in a certain issue area, e.g., as preparation for a visioning or modeling workshop. Methods such as RPG or SCA require more time and also more trust in the researchers and among the participants, and were therefore more suitable for the later stages of the participatory process. Methods such as interviews and focus or breakout groups were employed at any time during the process depending on the objective of a given activity. These findings are discussed in more detail below.

The following outlines the different methods used and the reasons for their selection:

\section{Cognitive Mapping and Group Model Building}

About midway through the project (September 2007), a "train-the-trainers" (TtT) workshop on participatory methods and their use within the context of adaptive management was held. The participants, who were mainly water practitioners and scientists from local institutes, learned about novel approaches in water management, especially the concept of adaptive management, and participatory methods that focused on Cognitive Mapping and Group Model Building. By the end of the course, trainees were able to give examples of how they were planning to apply this newly acquired knowledge in their (future) work - for instance, when conducting expert or stakeholder workshops or teaching activities. This training proved effective as several participants directly applied their new skills as facilitators of several workshops during later stages of the project. Due to this training and follow-up activities, the CM and GMB approaches have become almost a trademark of the NeWater project in Uzbekistan.

Subsequently, CM and GMB have been used in three different activities. Shortly after the TtT workshop, trainees were using it to facilitate an expert workshop on environmental flows. A different group of NeWater scientists used CM to identify indicators for community-based monitoring of soil salinity and wetland ecosystems. CM was used in several steps to structure farmers' local knowledge about soil salinity and expert knowledge provided by the local monitoring agency. The aim was to integrate the two types of knowledge in conceptual models of soil salinity. The models where then used as a basis for designing a monitoring system that integrates local knowledge with expert assessment (Giordano et al. 2008, Ozesmi and Ozesmi 2004). Finally, in three stakeholder workshops held in April 2008, CM and GMB were used as the main facilitation tools to discuss project results and develop visions for the near future. The exercises addressed three of the selected research issues: water and soil quality, wetland ecosystem services, and extreme events (the social dimension was covered in separate 
evaluation workshops. See Ex Post Analysis of the Participatory Activities, Focus groups, strategic choice approach, role-playing games ( Communitybased Research)). The time scale considered in the exercise was short term, i.e., the next 5-10 years, but was intended to go beyond the planning stage and develop visions as to how future water management might look. Through the modeling exercises, participants developed measures to address those three issues. Those measures informed ongoing and future research activities and were communicated to the management and policymaking levels in the final workshop.

CM and GMB were selected because they had proven successful in the TtT-workshop and followup activities where they were first used with smaller and more homogeneous groups on strongly focused issues, such as indicators for wetland ecosystem monitoring, before being applied to larger groups with a wide range of stakeholders. Both methods had succeeded in engaging people and avoiding some of the problems commonly experienced with workshop settings in the former Soviet republics, e. g., lack of open discussion, top-down decisions, and strong involvement of the officials in the process and outcomes of any kind of event.

\section{Nominal Group Technique}

The expertise of stakeholders from different management levels and their views and priorities concerning the current policy for coping with extreme events were identified using the NGT in a workshop held in September 2007. NGT was chosen because the knowledge about the issue of water deficit and coping strategies was dispersed among several stakeholders (water managers and practitioners). In addition, the NeWater team had considerable experience in the application of the NGT method in Uzbekistan. By using the method, it was possible to establish a structured collaborative working atmosphere, and to engage the participants and encourage them to express their opinions and contribute their knowledge in a fairly informal and nonhierarchical way.

Focus groups, strategic choice approach, roleplaying games (Community-based Research)

A CBR approach was chosen to incorporate the social dimension into water management and the development of measures for a transition to more adaptive forms of management. The activities of this research, which took place in the Amudarya River delta from 2006 to 2008, involved members of water user associations, the regional and local administration, representatives of fisheries communities, women from local communities, and people not represented by the official water management bodies (Matin 2009). As part of this process, the NeWater researchers, together with the rural communities in the river delta, investigated the importance of water resources management for human well-being and ecosystem sustainability. The community-based research took place in three distinct steps: public communication meetings that were open to all, informal focus group meetings with individual dialogue sessions, and feedback and validation workshops for farmers and fishermen. The third step involved the use of SCA, which is a method for structuring participant responses and is appropriate for late stages of the participatory process. These final workshops were coupled with the RPG activity. The RPG was used quite late in the research process as a supplementary experimental participatory activity with the objective of gathering information to build an agentbased model. Ideally, RPGs are used throughout a process as evolving interaction platforms between and with stakeholders. RPGs are both a form of restitution (researchers' understanding is given back through the model underlying the RPG) and a form of interview (stakeholders' options and motivations can be discussed on the basis of their actions in the RPG). They are not supposed to be used as a "one shot" in a research process, but in the given case study context, we wanted to test their ability to raise original discussions and genuine interactions among and with the participants. In the given cultural and political context, participants or interview partners often strongly self censor their answers and reactions. We wanted to test if the RPG method could create an environment where people could be less constrained. The RPG sessions proved to be a vivid experience and stuck in the memory of the participants, who discovered elements from their own situations in the games. The participants were very active and there was much lively exchange, in a friendly and informal way, including with facilitators. The main drawbacks were a lack of time, which resulted in insufficient training of facilitators, and language barriers, which made the final reframing through debriefing very inefficient and thus made it difficult to achieve a proper assessment of the exercise. Lack of time also resulted in a very low level of reporting and feedback. 
Because the RPG workshop was intended as a test to appraise the feasibility of the method in the Uzbek context, NeWater scientists did not design any procedure to disseminate the results to other members of the communities, other communities, or upper organizational levels. If further steps are to be taken with this method, it needs to be determined where, when, how, and what results should be disseminated. However, the NeWater researchers did make it clear during the introduction of the game that this was a form of experiment that might help participants understand their system better and make a model for this purpose, and also that it would provide a new and unaccustomed opportunity to exchange ideas.

\section{Adaptation of the methods to the local Uzbek context}

In general, the methods did not demand much adjustment because they are flexible techniques that are used in a broad variety of cultural contexts. In the case of the RPGs, which are to some extent the more customized tools because the games are adhoc creations (which is a time intensive process), the building methodology is the same as usual. For $\mathrm{CM}$ and GMB, the TtT-workshop set the foundation for the adaptation and application of those methods. The procedure of applying each method in a given activity, however, had to be adapted to account for the different views and expectations of the involved stakeholders regarding participation and the level of trust between organizers and participants. For example, in the development of a community-based monitoring system (which provides a low-cost improvement in the current monitoring system), the team had to carefully design participatory methods that took into account the general skepticism of the technically oriented bureaucrats towards local knowledge, as well as the motivation of local communities to take part in participative monitoring. In cooperation with the local agency, the European researchers designed their approach to increase the decision-makers' trust in locally based information on soil salinity, as well as the willingness of local communities to participate, e. g., by ensuring that the final soil salinity information would be fed back to the farmers.

\section{Assessment of the methods}

Table 4 provides a comparison of the seven participatory activities based on the evaluation framework and the scoring method described in the section The Participatory Activities and the Evaluation Framework, Evaluation framework and data and in Table A3.

Most of the methods achieved the objectives, i.e., improvement of the community members' understanding of the water management system and methods to monitor the state of the system. Participants appreciated the opportunity to develop a more holistic view of the problem by integrating the knowledge of stakeholders from different management levels or sectors, and to identify feasible measures to address different selected issues (e.g., drought). CM, in its various specifications, and GMB were particularly successful methods in this respect. The relatively low score of the CBR activities and focus group discussions in particular suggests there was uncertainty among the participants at the beginning of the project and participatory process. This might reflect the unfamiliarity of people in the local communities with being involved in a systems appraisal and research project, as well as their careful self censorship. However, as the research progressed, the participants seemed to gain confidence in expressing their own views. This is noted in the higher score for the validation workshops that were organized at the end of the research.

The following results are notable:

(1) Representation of stakeholders: The representation of stakeholders in most activities was high and their involvement was active. In three of seven activities this criterion was evaluated as moderate. This reduction can be attributed mainly to the fact that not all invited participants attended the workshops. However, the lack of attendance by some participants significantly affected the process and outcome of only one of the activities (assessment of institutional barriers for change). This activity was planned for eight participants who were working on different levels of water management: from the water distribution at the highest level of the subbasin to the WUAs and farms. All levels apart from the farm level were present. The absence of the farmers' representative was due to an urgent commitment linked to his main profession, which is different from farming. It is worth mentioning that after the land reform in Uzbekistan, people from many different backgrounds entered the farming business. In the case of this small workshop, the lack 
Table 4. Evaluation of the participative process (adapted from Rowe and Frewer 2000).

\begin{tabular}{|c|c|c|c|c|c|c|c|}
\hline Activity & $\begin{array}{l}\text { Assessment } \\
\text { of } \\
\text { institutional } \\
\text { barriers } \\
\text { for change }\end{array}$ & $\begin{array}{l}\text { Expert } \\
\text { workshop } \\
\text { on } \\
\text { environme- } \\
\text { ntal flows }\end{array}$ & $\begin{array}{l}\text { Community- } \\
\text { based } \\
\text { research on } \\
\text { social } \\
\text { aspects }\end{array}$ & $\begin{array}{l}\text { Community- } \\
\text { based } \\
\text { research- } \\
\text { validation }\end{array}$ & $\begin{array}{l}\text { Community- } \\
\text { based } \\
\text { research- } \\
\text { gaming } \\
\text { sessions }\end{array}$ & $\begin{array}{l}\text { Participative } \\
\text { design of } \\
\text { monitoring } \\
\text { system }\end{array}$ & $\begin{array}{l}\text { Participative } \\
\text { evaluation of project } \\
\text { findings }\end{array}$ \\
\hline Method applied & $\begin{array}{l}\text { Nominal } \\
\text { group } \\
\text { technique }\end{array}$ & $\begin{array}{l}\text { Cognitive } \\
\text { mapping } \\
\text { and Group } \\
\text { model } \\
\text { building }\end{array}$ & $\begin{array}{l}\text { Public } \\
\text { communic- } \\
\text { ation } \\
\text { meetings } \\
\text { and focus } \\
\text { group } \\
\text { discussions }\end{array}$ & $\begin{array}{l}\text { Strategic } \\
\text { choice } \\
\text { approach }\end{array}$ & $\begin{array}{l}\text { Role- } \\
\text { playing } \\
\text { game }\end{array}$ & $\begin{array}{l}\text { Cognitive } \\
\text { mapping }\end{array}$ & $\begin{array}{l}\text { Cognitive mapping } \\
\text { and Group model } \\
\text { building }\end{array}$ \\
\hline \multicolumn{8}{|c|}{ Acceptance criteria } \\
\hline $\begin{array}{l}\text { Representative- } \\
\text { ness of } \\
\text { participants }\end{array}$ & Moderate & Moderate & High & High & High & High & Moderate \\
\hline $\begin{array}{l}\text { Independence } \\
\text { of participants }\end{array}$ & Moderate & High & Low & High & Moderate & High & High \\
\hline $\begin{array}{l}\text { Early } \\
\text { involvement }\end{array}$ & High & High & High & High & High & High & High \\
\hline Transparency & High & High & Low & High & Low & High & High \\
\hline \multicolumn{8}{|l|}{ Process criteria } \\
\hline $\begin{array}{l}\text { Resource } \\
\text { accessibility }\end{array}$ & Moderate & High & Moderate & Moderate & Moderate & High & High \\
\hline Task definition & High & High & Low & High & High & High & Moderate \\
\hline $\begin{array}{l}\text { System } \\
\text { understanding }\end{array}$ & High & High & High & High & High & Moderate & High \\
\hline $\begin{array}{l}\text { Cost } \\
\text { effectiveness }\end{array}$ & High & High & High & High & High & High & High \\
\hline
\end{tabular}

of the lowest level's representative (a farmer) could have an impact on the overall result because his opinion and expertise was not represented. For other activities, the absence of a few selected participants was negligible because of the larger size of the events (30 to 50 participants). However, the participation of the higher administrative levels and the level of decision- and policy-makers, such as high-level water managers, was relatively weak. Higher level officials were sometimes prevented from attending by unexpected urgent meetings or other events related to their everyday activities. In some activities, their participation was not desirable because of their potentially strong dominance in an open discussion process. This was less of a problem in activities that used a structured approach, such as CM or NGT.

(2) Independence of participants: Most activities paid attention to the independence of participants. To achieve this, according to Rowe and Frewer (2000), it is necessary to "set an appropriate level or control for participants over the procedure and outputs of the exercise, i.e., allow participants to 
influence the way the exercise is run and the questions that are asked to the maximum of the level of sensible". This is a relevant criterion because in the past, when participatory methods were first introduced to Uzbekistan, the independence of participants was difficult to achieve for various reasons (e.g., lack of necessary contacts to access people and a pool of enumerators and experienced translators, lack of knowledge about the organizational structure of the water management system). In the given project, the NeWater team and the local partners could build on their experience with earlier projects, such as the Aral Sea Basin Vision (UNESCO 2000) and Amudelta (Schlüter et al. 2003), and on good contacts to projects currently being conducted in the Amudarya River delta (e.g., Khorezm project [ZEF/UNESCO; Zavgorodnyaya 2002, 2006; Wall 2006, Kan et al. 2008, Veldwish 2008]; Drainage, Irrigation and Wetlands Improvement project [World Bank 2003]). This greatly facilitated the organization of the participatory process within the project, i.e., the project activities were based on established networks from previous projects.

(3) Transparency: The NGT was not only simple to use, it was successful due to the involvement of a local facilitator, who was well known to the invited stakeholders and who was considered "one of them". This generated an environment of trust, which guaranteed an open atmosphere in the workshop. The NGT was used for the first time in Uzbekistan with these stakeholders, but the participants rated the method as easy to apply. Invited stakeholders were aware from the beginning of the activity what would happen with the results. After the event, they contributed to the evaluation of results via email. During the application of the $\mathrm{CM}$ and GMB, participants were informed about the flow of the workshop/event (see Ex Post Analysis of the Participatory Activities, Choice and application of the methods, Cognitive Mapping and Group Model Building). In comparison to the NGT, the feedback about the created group models based on $\mathrm{CM}$ and GMB exercises was delivered in the wrap-up session of the event.

(4) Task Definition: Most of the activities defined the task of the invited stakeholders clearly by means of (formal) invitations with pre-defined topics, which referred to previous project events where possible. However, during the events, not all tasks could be successfully carried out, e.g., the final step of identification of measures or the debriefing in the
RPG were cut short because of lack of time and capacity. The CBR scored low because it was designed as a more open-ended activity at the beginning of the field phase and was aimed at a general scoping and assessment of the major issues. As such, it did not have as well-defined tasks from the beginning.

(5) Cost-effectiveness: The methods chosen for the case study were considered appropriate because they were easy to operationalize, in most cases did not demand a large amount of preparation, and participation on average was high. Apart from this, time and financial means spent were well invested with regard to the gathered results because the potential costs of alternative methods, in terms of both time and money, were considered before the participatory method was applied.

The gaming sessions scored low on several criteria such as "transparency" and resource accessibility" because there was not enough time and immediate understanding of the behavior of the participants during the game to appropriately conduct the debriefing sessions. The language barrier between the participants and the RPG expert, as well as the lack of experience of the Uzbek moderators, appeared to be major hindering factors in this respect. Moreover, the RPGs were rather complex and time consuming, which made it difficult to involve participants in the evaluation of data or to clearly communicate how the information will be further analyzed. Lack of time affected the debriefing, where participants reflected on what happened during the game and why, and the development of a link between the RPG activities in the morning and the SCA activities in the afternoon (the activities were planned as interdependent events). It has to be noted, though, that the primary aim of the application of an RPG in the project was to test the feasibility of its application in the Uzbek context. In general, RPG activities should not be used only once, but rather should be applied several times during a participative process.

\section{Enhancement of system understanding}

During the scoping workshops at the beginning of the project, one of the most prominent issues voiced repeatedly by the stakeholders was the lack of data for forecasting water availability due to the deterioration of the monitoring infrastructure and changes in bilateral cooperation between river basin 
countries after the breakup of the Soviet Union. This was often seen as the single cause of the current water management problems in the downstream part of the river basin. It was assumed that once the technical infrastructure and forecasting system was functional again, the water management issues would be resolved. During the course of the participatory activities, e.g., the assessment of institutional barriers to change and the participative evaluation of project findings, we observed that other factors related to the institutional settings or human capital, such as the lack of an integrated water policy that takes all water users into account or the need for strengthening the decision-making mandate of local agencies, were discussed and included in the assessment. This shift towards a more multi-faceted view of the issues was in part achieved by the use of participatory methods that gave each participant the opportunity to systematically contribute their own view on the problems to the overall picture and the resultant enhancement of system understanding. However, our aim to use the GMB exercise for a participative evaluation of project findings was only moderately successful. Most participants were very eager to contribute their own views on a specific problem and were less interested in discussing the more complex preliminary results of the project. In part, this might be explained by the general lack of a discussion culture but also by the difficulties in communicating a more complex picture that had been synthesized from the previous activities and research. The integration of the scientific understanding of the selected issues with the stakeholder perceptions, which was the aim of the activity, was thus carried out by the project team after the workshops.

At the beginning of the participatory monitoring design process, state officials involved in soil and water salinity monitoring were skeptical about the capabilities of local communities to provide useful knowledge. At the same time, local communities, and particularly farmers, were aware of the topdown approach to decision-making, and consequently, often believed that decisions will be made elsewhere even if a participatory approach is adopted. In the end, the participatory monitoring design resulted in increased acceptability of locally-based information by the employees of the state monitoring agency (Giordano et. al. 2010). The process also increased farmers' awareness about and confidence in the value of their knowledge. Experienced farmers emphasized the importance of feeding the information about trends in soil salinity back to the farmers in order to increase their awareness of the severity of the problem and enhance understanding of factors impacting soil salinity. Moreover, the combination of local and technical knowledge and the sharing of the results of soil salinity assessment can potentially improve the capabilities of less experienced farmers to qualitatively assess soil salinity at the beginning of the leaching period. This in turn can lead to a more sustainable use of water for leaching and irrigation.

The activities also contributed to an enhanced system understanding among the involved scientists. The design, implementation, test, and debriefing discussions of the RPG, for example, provided a platform for involving Uzbek colleagues as well as local practitioners in explaining knowledge gaps and inconsistencies in the understanding of the water management system in the lower Amudarya River basin.

\section{DISCUSSION AND CONCLUSIONS}

A variety of participatory methods have been used in the Uzbek part of the Amudarya basin as a case study of the NeWater project. These methods have been applied by different scientists, in different activities dealing with different issues. The assessment of these activities and the methods used show similarities as well as some noticeable differences in their usefulness or acceptability in Uzbekistan.

Generally, participants appreciated the opportunity to contribute their own views and ideas on a specific problem in a structured procedure. The exercises were conceived as useful joint brainstorming that provided the participants with a more integrated perspective on the problems. Moreover, stakeholders from the local and regional levels were keen about the fact that NeWater researchers could bring their concerns to the attention of higher level bureaucrats. The latter are often not accessible to them and do not value the knowledge of people on the ground. Giordano et al. (2008) explained the reluctance of policy-makers to accept local knowledge in environmental resource management: "Local knowledge is qualitative and unstructured, based on experiences and stories, and therefore not easily comprehensible for the decision makers and functional for the decision process". Moreover, the strong hierarchical organization of water and land 
management in the past nourished an attitude among state officials that the farmers are not knowledgeable and need to be instructed. The participation of stakeholders in our research thus raised expectations about, for example, the impact of the event on the decision making process or on tools and instruments to improve management of natural resources, which the organizers of a participatory event have to be aware of and take into account, e.g., by clearly stating how the results of the activities will be further used.

On the whole, our analysis and comparison of the application of different participatory methods to address water management issues in Uzbekistan revealed both potential for improvement and obstacles for application. In general, all the methods selected were accepted by the stakeholders and supported stakeholder participation in the assessment of the current regime and identification of measures to facilitate a transition to adaptive management. CM, GMB, and NGT were most effective in facilitating stakeholder participation. The advantage of these methods was that (1) they did not need simultaneous translation during the process, (2) the processes could be easily moderated by local facilitators, and (3) debriefing was done by the representative of the working breakout group. Some of the lower scores of the community-based research, particularly of the focus group discussions at the beginning of the activity, might reflect the unfamiliarity of people in the local communities with being involved in a systems appraisal and research project, as well as their careful self censorship.

The RPG seemed to be very interesting for the participants, increased active involvement in the process, and had the potential to reveal information on decision-making processes in water management that are difficult to address using more static methods. The obstacles to using this method were insufficient time, which accentuated on-stage problems of managing the game, including the need for simultaneous translation and use of the conversations during the game for moderation and debriefing. "Complex" methods such as RPG need to be used repeatedly in order to increase experience and knowledge and to validate the scientific results, but it should be supported by adequate resources and time.

Time requirement is a crucial issue that should be considered when preparing an event involving the use of participatory methods. In particular, the preparation of the facilitation team for CBR, SCA, and RPG events proved to be very time-consuming. Another timing aspect is that in rural areas, people working in agriculture and water management are busy with seasonal activities throughout the year. The RPG and CBR validation, for example, could not involve all stakeholders as planned because the event had to be postponed for political reasons to the beginning of the growing season when the farmers were busy preparing the fields.

Our experience shows that in order to choose and adapt participatory methods to the Uzbek cultural and political setting, and most likely this applies to other post-Soviet transition countries as well, four aspects should be taken into account: (1) the time required to prepare and apply the method, (2) the availability of good information about the participants and the context in which the method will be applied, (3) the need for knowledge of the local language(s), and (4) the need for careful training of local moderators. Moreover, in some of activities, the involvement of the decision-maker level was purposefully minimized to avoid influencing the rest of the invited group. At the same time, in Uzbekistan, the support of (local) officials, such as the regional or provincial governors, enhances the discipline and attendance of other stakeholders in the activity. While these aspects are relevant to any application of participatory methods, they become even more important in a political and socio-cultural setting such as that found in Uzbekistan. The extent to which those issues are relevant for a given method depends on the method itself, e.g., the demands on knowledge of the local language and context (e.g., distribution of power and social relationships between participants) are high for an RPG but low for the NGT.

We found that the potential of a participatory research process, such as the one described in this paper, to enhance the policy making process in Uzbekistan lies in facilitating communication and establishing a link between different levels of water governance and water users, e.g., by providing a means of integrating local level knowledge and visions into assessment and monitoring. Our participatory activities generated interest among some members of the middle level administration who saw them as a means to learn about the needs and perceptions of "their" water users in order to improve their policy making. Another positive outcome is the capacity building of local scientists 
in government-related institutes in the use of participatory methods to improve their assessment and project implementation. An example, there is an Uzbek government wetland restoration project to which our wetland ecosystem services activities were linked. It also serves as an example for deliberation processes that, with the introduction of community-based management, will potentially become more relevant.

To conclude, the following lessons were learned from the comparison of the different participatory methods used:

1. The stakeholder process provided an opportunity for meetings and discussions among stakeholders from different levels, $i$. e., from the local to the national levels, and thus promoted communication between different levels and organizations.

2. When initiating a participatory process in a context where most stakeholders are not generally involved in policy-making, there is a danger of awakening expectations, e.g., of representing local interests to higher levels, that a research project cannot meet. However, it does help to link the different administrative or hierarchical levels by facilitating information flows between them.

Overall, the application of the different participatory methods with their adaptation to the case region contributed to improved system understanding and - potentially - learning among both stakeholders and researchers, which is at the core of the adaptive management process. We are aware that a 4-year research project can provide only a few illustrative examples of the usefulness of participation in system assessment in the river basin. For this reason, the capacity building aspect of the activities seems to be crucial. The application of participatory methods in the Amudarya case study after the termination of the project is being continued by local partners who received the knowledge and capacity as well as material to integrate some of the methods into their projectrelated work or teaching.
Responses to this article can be read online at: http://www.ecologyandsociety.org/vol15/iss3/art23/ responses/

\section{Acknowledgments:}

We thank all participating stakeholders for their involvement and for the generosity with which they shared their experiences with us. We express our deep gratitude to U. Abdullaev, I. Joldasova, M. Khalmirzaeva, G. Khasankhanova, A. Salokhiddinov, $G$. Tilyavova, and R. Toryannikova for their great cooperation, engagement in, and support of the participatory activities. We are grateful to Patricia Stadie for her efforts in proofreading the paper. We thank two anonymous reviewers of our manuscript for their critical reading and valuable comments. The research presented in this paper was funded by the European Commission (Contract $N^{\circ} 511179$ NEWATER). Maja Schlüter acknowledges the support of a Marie Curie International Fellowship within the 6th European Community Framework Programme.

\section{LITERATURE CITED}

Abrami, G., and M. Schlüter. 2009. Building an agent-based model for exploring how informal rules impact the functioning of newly-established Water User Associations in Central Asia. Proceeding of the Congress of the European Social Simulation Association, September 14-18, 2009, University of Surrey, Guildford, UK.

Adams, L. 1999. Invention, institutionalization and renewal in Uzbekistan's national culture. European Journal of Cultural Studies 2(3):355-373.

Barreteau, O. et al. 2003. Our companion modelling approach. Journal of Artificial Societies and Social Simulation 6(1). [online] URL: http://ja sss.soc.surrey.ac.uk/6/2/1.html.

Barreteau, O., C. Le Page, and P. Perez. 2007. Contribution of simulation and gaming to natural resource management issues: an introduction. Simulation and Gaming 38(2):185-194.

Borowski, I., and M. Hare. 2007 Exploring the gap between water managers and researchers: 
difficulties of model-based tools to support practical water management. Water Resources Management 21(7): 1049-1074.

Bousquet, F., O. Barreteau, P. d'Aquino, M. Etienne, S. Boissau, S, Aubert, C, Le Page, D. Babin, and J.-C. Castella. 2002. Multi-agent systems and role games: collective learning processes for ecosystem management. Pages 249285 in M. A. Janssen, editor. Complexity and ecosystem management: the theory and practicse of multi-agent systems. Edward Elgar, Cheltenham, UK.

CACILM. 2006. Country pilot partnerships on sustainable land management. CACILM Multicountry Partnership Framework. Executive Summary. [online] URL: http://www.adb.org/Documents/CA CILM/CACILM-Partnership-FrameworkExecutiveSummary.pdf.

Centre for Economic Research and United Nations Development Programme (CER and UNDP). 2005. Linking macro-economic policy to poverty reduction in Uzbekistan. Centre for Economic Research and United Nations Development Programme, Uzbekistan. [online] URL: http://unpa n1.un.org/intradoc/groups/public/documents/apcity/ unpan023584.pdf.

Dukhovny, V. 2005. The creation of capacity development of interstate water collaboration in the Aral Sea Basin. Workshop Proceedings on Design and Implementation of Capacity Development Strategies. Final report. Beijing, China.

Environmental Resources Management (ERM). 2003. JEP 11 : South Karakalpakstan Main Collector Drain Project, Uzbekistan Volume II: Social Impact Assessment Report. EC Tacis-funded Joint Environmental Programme. [online] URL: http://www-wds.worldbank.org/external/default/ WDSContentServer/WDSP/IB/2003/04/05/000094 $9460303220424325 /$ Rendered/PDF/multi0page.pdf

Fortmann, L., editor. 2008. Participatory research in conservation and rural livelihoods: doing science together. Wiley-Blackwell.

Friend, J., and A. Hickling. 1997. Planning under pressure - the strategic choice approach. Elsevier Butterworth-Heinemann, Oxford, UK.
Funtowicz, S., and J. Ravetz. 1993. Science for the post-normal age. Futures 25(7):739-755.

Giordano, R., S. Liersch, M. Vurro, and D. Hirsch. 2010. Integrating local and technical knowledge to support soil salinity monitoring in the Amudarya River basin. Journal of Environmental Management 91(2010):1718-1729.

Giordano, R., S. Liersch, M. Vurro, and V. Uricchio. 2008. The integration of expert and stakeholder cognitive models to support environmental monitoring. Pages 880-887 in M. Sànchez-Marrè, J. Béjar, J. Comas, A. Rizzoli, and G. Guariso, editors. Proceedings of the iEMSs 2008: International Congress on Environmental Modelling and Software Integrating Sciences and Information Technology for Environmental Assessment and Decision Making 4th Biennial Meeting of iEMSs. [online] URL: http://www.iemss.org/iemss2008/up loads/Main/S10-07-Giordano_et_al-IEMSS2008.pdf

Hanssen, L., E. Rouwette, and M. van Katwijk. 2009. The role of ecological science in environmental policy making: from a pacification toward a facilitation strategy. Ecology and Society 14(1):43. [online] URL: http://www.ecologyandsoc iety.org/vol14/iss1/art43/.

Harding, R. 1998. Environmental decisionmaking: the role of scientists, engineers and the public. Federation Press.

Hartley, T., and R. Robertson. 2006. Stakeholder engagement, cooperative fisheries research and democratic science: the case of the northeast consortium. Human Ecology 13(2):161-171. [online] URL: http://www.humanecologyreview.org/ pastissues/her132/hartleyrobertson.pdf.

Herbst, S. 2006. Water, sanitation, hygiene and diarrheal diseases in the Aral Sea area (Khorezm), Uzbekistan). Dissertation. Cuvillier Publishing, Goettingen, Germany.

Holling, C. 1978. Adaptive environmental assessment and management. Wiley, Chichester, UK.

IWMI. 2002. Institutional situation analysis of water management in the Ferghana Valley, January 2002. Integrated Water Management in the Ferghana Valley Project (IWMFVP) (WA 300701). 
IWMI, Colombo, Scientific Information Center of the Interstate Commission on Water Coordination (SIC-ICWC), Tashkent, Uzbekistan.

Jalling, L. 2006. Environmental issues of Central Asia. A source for hope or despair? Pages 167-188 in B. Everett and R. Heath, editors. Central Asia. Aspects of transition. Routledge Curzan.

Jeffrey, P., W. Medema, and B. McIntosh. 2008. From premise to practice: a critical assessment of integrated water resources management and adaptive management approaches in the water sector. Ecology and Society 13(2):29. [online] URL: http://www.ecologyandsociety.org/vol13/iss2/art29/

Kan, E. 2006. The assessment of agro forestry systems in Khorezm: farmer's perceptions and practice. Thesis. Urgench State University, Uzbekistan.

Kan, E., J. Lamers, R. Eschanov, and A. Khamzina. 2008. Small-scale farmers' perceptions and knowledge of tree intercropping systems in the Khorezm region of Uzbekistan. Forests, Trees and Livelihoods 18 (4):363-381.

Kranz, N., H. Gerdes, and C. Laaser. 2008. A river runs through it: transboundary water in the Amudarya Basin. Schlossplatz Fall (5):13-15.

Kranz, N., E. Interwies, and A. Vorwerk. 2005. Transboundary river basin management regimes: the Amu Darya basin case study. Ecologic-Institute for International and European Environmental Policy, Berlin, Germany.

Kranz, N., A. Vorwerk, and R. Vidaurre. 2007. Towards adaptive water governance observations from two transboundary river basins. International Conference on Adaptive and Integrated Water Management CAIWA conference, 12-15 November 2007, Radisson SAS Hotel Basel, Switzerland. [online] URL: http://www.newater.info/caiwa/data/ papers\%20session/F3/Kranz Ecologic CAIWA tr ansboundary governance.pdf.

Laumonier, Y., R. Bourgeois, and J.-L. Pfund. 2008. Accounting for the ecological dimension in participatory research and development: lessons learned from Indonesia and Madagascar. Ecology and Society 13(1):15. [online] URL: www.ecology andsociety.org/vol13/iss1/art15.
Lee, K. 1999. Appraising adaptive management. Conservation Ecology 3(2):3. [online] URL: http:// www.ecologyandsociety.org/vol3/iss2/art3/.

March, A. 2003a. From Leninism to Karimovism: hegemony, ideology, and authoritarian legitimation. Post-Soviet Affairs 19(4):307-336.

March, A. 2003b. State ideology and the legitimation of authoritarianism: the case of postSoviet Uzbekistan. Journal of Political Ideologies 892:209-232.

Martin, A., and J. Sherington. 1997. Participatory research methods-implementation, effectiveness and institutional context. Agricultural Systems 55 (2):195-216.

Matin, N. 2009. Achieving sustainable water management in Uzbekistan: visions of farmers and fishermen. Report of the NeWater project New Approaches to Adaptive Water Management under Uncertainty. [online] URL: www.newater.info/intern/ sendfile.php?id=1317.

Médecins Sans Frontières (MSF). 2003. Karakalpakstan: a population in danger. The impact of the Aral Sea disaster and a worsening economic climate on the health and wellbeing of the people of Karakalpakstan. [online] URL: http://www.msf. org/source/countries/asia/aralsea/2003/karakalpakstan/ complete.pdf.

Middendorf, G., and L. Busch. 1997. Inquiry for the public good: democratic participation in agricultural research. Agriculture and Human Values 14:45-57.

Ministry of Agriculture and Water Resources Management of the Republic of Uzbekistan (MAWR). 2003. Draft executive summary of the environmental assessment and environmental management plan for the Drainage, Irrigation and Wetlands Improvement Phase I-Project, Tashkent, Uzbekistan. [online] URL: http://www-wds.worldb ank.org/external/default/WDSContentServer/WDSP/ IB/2003/04/05/000094946 0303220424322/Rendered/ PDF/multi0page.pdf.

Mirzaev, N., and R. Saidov. 2008. Rol' obshesvennogo uchastiya $v$ povyshenii spravedlivosti I effektivnosti upravleniya vodoi IWMI, SIC ICWC, SDC, Tashkent, Uzbekistan. 
Neef, A. 2009. Transforming rural water governance: towards deliberative and polycentric models? Water Alternatives 2(1):53-60.

Oliver, P., J. Whelan, and J. Mackenzie. 2005. Barriers and bridges to collaborative natural resource management in South East Queensland. Indooroopilly, Queensland, Australia: Coastal CRC. [online] URL: http://www.ozcoasts.org.au/pdf/ CRC/19-Barriers Bridges.pdf.

Ozesmi, U., and A. Ozesmi. 2004. A participatory approach to ecosystem conservation: fuzzy cognitive maps and stakeholder groups analysis in Uluabat Lake, Turkey. Environmental Management 31(4):518-531. [online] URL: http://www.springer link.com/content/bbh1gpk3p0k2fyj9/fulltext.pdf.

Pahl-Wostl, C., J. Moeltgen, E. Ebenhoeh, and G. Holtz . 2007. The NeWater management and transition framework-state and development process. Pages: 78-96 in C. Pahl-Wostl, P. Kabat, and J. Moeltgen, editors. Adaptive and integrated water management. Coping with complexity and uncertainty. Springer, Berlin Heidelberg.

Rowe, G., and L. Frewer. 2000. Public participation methods: an evaluative review of the literature. Science, Technology and Human Values 25:3-29.

Sample, J. 1984. Nominal Group Technique: an alternative to brainstorming. Journal of Extention 22(2). [online] URL: http://www.joe.org/joe/1984m arch/iw2.html

Santhakumar, V. 2001. Analysing failed participation with the perspective of new institutional economics. In V. Bhaskar and $\mathrm{R}$. Jeffery, editors. Analytical issues in participatory natural resources. Palgrave Macmillan.

Schlüter, M., D. Hirsch, U. Abdullaev, E. Herrfahrdt-Pähle, R. Giordano, M. Khamirzaeva, G. Khasankhanova, N. Kranz, S. Liersch, N. Matin, A. Salokhiddinov, A. Savitsky, C. Siderius, R. Toryannikova. 2010. The Amudarya case study. Pages 143-157 in J. Mysiak, H.J. Henriksen, C. Sullivan, J. Bromley, and C. PahlWostl, editors. The adaptive water resource management handbook. Earthscan, London.
Schlüter, M., G. Khasankhanova, U. Abdullaev, V. Talskikh, R. Taryannikova, I. Joldasova, T. Khamzina, R. Ibragimov, and C. Pahl-Wostl. 2007. Incorporating environmental flows into water management in the Amudarya River delta. International Conference on Adaptive and Integrated Water Management CAIWA conference, 12-15 November 2007, Radisson SAS Hotel Basel, Switzerland. [online] URL: http://www.newater.uos. de/caiwa/data/papers $\% 20$ session/H2/Schlueter et al final. pdf.

Schlüter, M. A., and H. Lieth. 2005. Restoration and management options for aquatic and tugai ecosystems in the northern Amudarya delta region. Final report Intas - aral sea-00-1039. [online] URL: http://www.usf.uni-osnabrueck.de/projects/aral.

Schlüter, M., A. Salokhiddinov, and D. Hirsch. 2009. Approaches to adaptive water management in the Amudarya River Basin. Booklet with NeWater case study results. [online] URL: http://www.newa ter.info/index.php?pid=1010.

Sclove, R., M. Scammell, and B. Holland. 1998. Community-based research in the United States: an introductory reconnaissance including twelve organizational case studies and comparison with the Dutch science shops and with the mainstream American research system. The Loka Institute, Washington, D.C., USA.

SEECON. 2007. Participatory management - a brief guideline for water managers. Technical Report 7. Osnabrueck, Germany.

Sehring, J. 2009. Path dependencies and institutional bricolage in post-Soviet water governance. Water Alternatives 2(1):61-81.

Shirokova, Y., and A. Morozov. 2006. Salinity of irrigated lands of Uzbekistan: causes and present state. Pages 249-259 in A. Khan, B. Boer, G. Kust, and H.-J. Barth, editors. Sabkha Ecosystems, Volume II: West and Central Asia. Springer.

Sokolov, V. 2008. Central Asia: water shortage due to lack of regional agreements, prompt decisionmaking. [online] URL: http://enews.ferghana.ru/art icle.php?id=2422.

Spoor, M. 2004. Agrarian restructuring and trends in rural inequalities in Central Asia: a socio- 
statistical survey. Civil Society and Social Movements Programme Paper 13. UNRISD, Geneva, Switzerland.

Stoecker, R. 2004. Creative tensions in the new community based research. Keynote for the Community Based Research Symposium. May 13, 2004, Carleton University, Ottawa, Canada. [online] URL: http://comm-org.wisc.edu/drafts/cbr tensions.htm.

Stringer, L., A. Dougill, E. Fraser, K. Hubacek, K. Prell, and M. Reed. 2006. Unpacking "participation" in the adaptive management of social-ecological systems: a critical review. Ecology and Society 11(2):39. [online] URL:http:// www.ecologyandsociety.org/vol11/iss2/art39/.

Thurman, M. 2002. Irrigation and poverty in Central Asia: a field assessment. [online] URL: $\underline{\mathrm{htt}}$ p://waterwiki.net/images/9/9e/IrrigandPovertyInCAvers2Thurman.pdf.

UNEP. 2005. UNEP Support for achieving the Johannesburg Plan of implementation target of "Integrated Water Resources Management and Efficiency Plans by 2005" with support to developing countries. Sub-regional Programme for Central Asia. UNEP Collaborating Centre for Water and Environment (UCC-Water) and UNEP in close consultation with GWP CACENA (and coordinated with UNDP and UNECE).

Vardanyan, A., and L. Abrahamyan. 2009. PRSP participatory process in Armenian: lessons learned. Transit Studies Review 15:737-745. [online] URL: http://www.springerlink.com/content/b775632475156892/ fulltext.pdf.

Veldwish, G. 2008. Cotton, rice \& water: transformation of agrarian relations, irrigation technology and water distribution in Khorezm, Uzbekistan. Dissertation. University of Bonn, Germany. [online] URL: http://www.zef.de/fileadmin/ webfiles/downloads/projects/khorezm/downloads/ Publications/Doctoral Theses/Veldwisch 2008.pdf

Vennix, J. 1996. Group model building: facilitating team learning using systems dynamics. John Wiley $\&$ Sons, New York, USA.

Wall, C. 2006. Knowledge management in rural Uzbekistan: peasant, project and post-socialist perspectives in Khorezm. Dissertation. University of Bonn, Germany. [online] URL: http://deposit.ddb. de/cgi-bin/dokserv?idn=983673187\&dok var= d1\&dok ext=pdf\&filename=983673187.pdf.

Walters, C. 1986. Adaptive management of renewable resources. Macmillan and Co., New York, New York, USA.

Witteveen, L., and B. Enserink. 2007. Cultural issues in making and using the visual problem appraisal "Kerala's Cost". Knowledge, Technology \& Policy 19(4):94-118.

World Bank. 2003. Uzbekistan: drainage, irrigation and wetlands improvement project Phase I. Project Appraisal Document.

Yalcin, R., and P. Mollinga. 2007. Institutional transformation in Uzbekistan's agricultural and water resources administration: the creation of a new bureaucracy. ZEF Working Papers Series 22:1-40.

Zavgorodnyaya, D. 2002. Lokale Organization des Wassermanagements in der Region Khorezm, Usbekistan. Thesis. University Bonn, Germany.

Zavgorodnyaya, D. 2006. Water user associations in Uzbekistan: theory and practice. Dissertation. Cuvillier Publishing, Goettingen, Germany. 
Table A.1 Overview of applied participative methods in Uzbekistan

\begin{tabular}{|c|c|c|}
\hline $\begin{array}{l}\text { Participative } \\
\text { method }\end{array}$ & Aim for application & Applied in \\
\hline $\begin{array}{l}\text { Community } \\
\text { interview }\end{array}$ & $\begin{array}{l}\text { To find out about perceptions of health } \\
\text { problems in the region }\end{array}$ & \multirow{5}{*}{$\begin{array}{l}\text { Water sanitation, hygiene and } \\
\text { diarrheal diseases in the Aral sea } \\
\text { area (Khorezm, Uzbekistan) } \\
\text { (Herbst, 2006), PhD work, ZEF- } \\
\text { UNESCO Project }\end{array}$} \\
\hline Spot checks & $\begin{array}{l}\text { To gather data about domestic hygiene } \\
\text { conditions }\end{array}$ & \\
\hline $\begin{array}{l}\text { Socio-hygienic } \\
\text { mapping (scheme) }\end{array}$ & $\begin{array}{l}\text { To gain insight into the number of families } \\
\text { that constituted a household and into the } \\
\text { prevailing hygienic conditions }\end{array}$ & \\
\hline Diarrhea diary & To measure incidents of diarrheal disease & \\
\hline Questionnaire & To expose risk factors & \\
\hline Group discussion & To gather data about functioning of WUAs & \multirow{7}{*}{$\begin{array}{l}\text { Water users association in the } \\
\text { Republic of Uzbekistan: Theory } \\
\text { and practice (Zavgorodnyaya, } \\
\text { 2006), PhD work, ZEF- } \\
\text { UNESCO Project }\end{array}$} \\
\hline $\begin{array}{l}\text { Role-playing } \\
\text { games }\end{array}$ & $\begin{array}{l}\text { To gain insight into the decision-making } \\
\text { sequences in water management }\end{array}$ & \\
\hline $\begin{array}{l}\text { Participatory rural } \\
\text { appraisal (PRA): } \\
\text { Social mapping }\end{array}$ & To gain insight about structure & \\
\hline $\begin{array}{l}\text { Participatory rural } \\
\text { appraisal (PRA): } \\
\text { Pros and Contras }\end{array}$ & \multirow[t]{3}{*}{$\begin{array}{l}\text { To find out about necessity of WUAs in the } \\
\text { region }\end{array}$} & \\
\hline Brainstorming & & \\
\hline $\begin{array}{l}\text { Nominal group } \\
\text { technique }\end{array}$ & & \\
\hline $\begin{array}{l}\text { Standardized } \\
\text { questionnaire }\end{array}$ & $\begin{array}{l}\text { Focused on the farmers' perceptions on the } \\
\text { WUAs as self-governance organization }\end{array}$ & \\
\hline $\begin{array}{l}\text { Participating } \\
\text { observer and } \\
\text { observed } \\
\text { participant }\end{array}$ & $\begin{array}{l}\text { To be integrated into the community, } \\
\text { generating a richness of observational data } \\
\text { and insight }\end{array}$ & \multirow{2}{*}{$\begin{array}{l}\text { Knowledge management in } \\
\text { rural Uzbekistan (Wall, 2006), } \\
\text { PhD work, ZEF-UNESCO } \\
\text { Project }\end{array}$} \\
\hline $\begin{array}{l}\text { Living in 'the } \\
\text { field' }\end{array}$ & $\begin{array}{l}\text { To gain a distance from the project group, } \\
\text { whilst concurrently winning increased } \\
\text { levels of } \\
\text { empathy (or at least curious bemusement) } \\
\text { from the rural farming group }\end{array}$ & \\
\hline (Participant) & To develop an understanding of the & \multirow{4}{*}{$\begin{array}{l}\text { Transformation of agrarian } \\
\text { relations, irrigation technology } \\
\text { and water distribution in } \\
\text { Khorezm, Uzbekistan } \\
\text { (Veldwish, 2008), PhD work, } \\
\text { ZEF-UNESCO Project }\end{array}$} \\
\hline observations & $\begin{array}{l}\text { Khorezmian agrarian system and ways of } \\
\text { securing access to irrigation water }\end{array}$ & \\
\hline Household survey & $\begin{array}{l}\text { To gather basic statistical data on } \\
\text { household composition, land holding and } \\
\text { land-use }\end{array}$ & \\
\hline Living in a village & $\begin{array}{l}\text { To overcome the farmers'hesitance to talk } \\
\text { and the frequent miscommunications due to } \\
\text { cultural and language barriers }\end{array}$ & \\
\hline $\begin{array}{l}\text { "Snowball" } \\
\text { sampling }\end{array}$ & $\begin{array}{l}\text { Farmers selected by random sampling were } \\
\text { asked to nominate other individuals in their } \\
\text { vicinity }\end{array}$ & \multirow{2}{*}{$\begin{array}{l}\text { The assessment of agroforestry } \\
\text { systems in Khorezm: farmer's } \\
\text { perceptions and practice (Kan, } \\
\text { 2006), Master thesis, ZEF- } \\
\text { UNESCO Project }\end{array}$} \\
\hline $\begin{array}{l}\text { Participatory rural } \\
\text { appraisal (PRA): } \\
\text { Questionnaires }\end{array}$ & $\begin{array}{l}\text { To survey private owners or land renters in } \\
9 \text { districts of Khorezm regarding their } \\
\text { perception on tree intercropping systems in } \\
\text { the Khorezm, Uzbekistan }\end{array}$ & \\
\hline $\begin{array}{lr}\text { Needs } & \text { assessments } \\
\text { and } & \text { conflict } \\
\text { analyses } & \\
\end{array}$ & $\begin{array}{l}\text { To engage local communities in an analysis } \\
\text { of community-land interactions }\end{array}$ & \multirow{5}{*}{$\begin{array}{l}\text { ADB and UNCCD-National } \\
\text { programming framework: } \\
\text { Central Asian Countries } \\
\text { Initiative for Land Management } \\
\text { (CACILM), Project time: } 2005 \text { - } \\
2015\end{array}$} \\
\hline Participatory & To assess needs, context, and impact at the & \\
\hline $\begin{array}{l}\text { Rural } \\
\text { (PRA) }\end{array}$ & community level & \\
\hline $\begin{array}{l}\text { Socio-economic } \\
\text { surveys }\end{array}$ & \multirow{2}{*}{$\begin{array}{lll}\text { To enhance } & \text { primary } & \text { stakeholder } \\
\text { participation in } & \text { analyzing } & \text { community } \\
\text { issues, assessing } & & \\
\text { community needs, program planning, and }\end{array}$} & \\
\hline $\begin{array}{l}\text { Community } \\
\text { mapping }\end{array}$ & & \\
\hline
\end{tabular}




\begin{tabular}{|c|c|c|}
\hline Conflict analysis & evaluation of program impact & $\begin{array}{r}\text { Ecology } \\
\text { httn://www.ecologvandsociet }\end{array}$ \\
\hline $\begin{array}{l}\text { Participative } \\
\text { method }\end{array}$ & Aim for application & Applied in \\
\hline $\begin{array}{l}\text { Stakeholder } \\
\text { analysis }\end{array}$ & & $\begin{array}{l}\text { ADB and UNCCD-National } \\
\text { programming framework: } \\
\text { Central Asian Countries } \\
\text { Initiative for Land Management } \\
\text { (CACILM), Project time: 2005- } \\
2015\end{array}$ \\
\hline $\begin{array}{l}\text { Rural Rapid } \\
\text { Appraisal (PRA) }\end{array}$ & For collection of baseline data & \multirow{5}{*}{$\begin{array}{l}\text { IWMI: Integrated Water } \\
\text { Management in the Ferghana } \\
\text { Valley Project (IWMFVP), } \\
\text { Project time. 2002-2008 }\end{array}$} \\
\hline Questionnaire & $\begin{array}{l}\text { Baseline survey in three WUAs/Follow-up } \\
\text { survey in three WUAs }\end{array}$ & \\
\hline $\begin{array}{l}\text { Identification of } \\
\text { Social Organiser } \\
\text { Volonteers (SOV) }\end{array}$ & $\begin{array}{l}\text { To avoid farmers mistrust from the start, } \\
\text { intervening and entering into the farming } \\
\text { community through the local rural people, } \\
\text { as much as possible }\end{array}$ & \\
\hline Group discussions & $\begin{array}{l}\text { For the participative nature of the training } \\
\text { of SOVs }\end{array}$ & \\
\hline $\begin{array}{l}\text { Rapport-building } \\
\text { meeting }\end{array}$ & $\begin{array}{l}\text { To build a rapport with farming } \\
\text { community, sharing information on the } \\
\text { project, WUAs, their roles and } \\
\text { responsibilities, benefits and authority, etc, } \\
\text { concept clearance, diffusing } \\
\text { misconceptions, doubts and rumors, if any, } \\
\text { prevalent in the area or among the water } \\
\text { users }\end{array}$ & \\
\hline
\end{tabular}


Table A2. List of stakeholders in the participative activities

Ecology and Society 15(3): 23

\begin{tabular}{|c|c|c|c|c|}
\hline & Topic & Participants & Where & When \\
\hline 1 & $\begin{array}{l}\text { Local community } \\
\text { needs }\end{array}$ & $\begin{array}{l}\text { members of water user } \\
\text { association }\end{array}$ & Khorezm & Sep 07 \\
\hline 2 & $\begin{array}{l}\text { Local community } \\
\text { needs }\end{array}$ & $\begin{array}{l}\text { members of fishery } \\
\text { community }\end{array}$ & Karakalpakstan & Sep 07 \\
\hline 3 & $\begin{array}{l}\text { Coping with } \\
\text { extreme events }\end{array}$ & $\begin{array}{ll}\text { representatives } & \text { from } \\
\text { regional authorities, river } \\
\text { basin organization, scientific } \\
\text { institutes }\end{array}$ & Urgench & Sep 07 \\
\hline 4 & $\begin{array}{l}\text { Environmental } \\
\text { Flows }\end{array}$ & $\begin{array}{l}\text { local experts on hydrology, } \\
\text { ecology and social issues }\end{array}$ & Nukus & Sep 07 \\
\hline 5 & $\begin{array}{l}\text { Validation of } \\
\text { research results }\end{array}$ & $\begin{array}{l}\text { members of water user } \\
\text { association, women }\end{array}$ & Urgench & Apr 08 \\
\hline 6 & $\begin{array}{l}\text { Validation of } \\
\text { research results }\end{array}$ & $\begin{array}{l}\text { members of water user } \\
\text { association, women }\end{array}$ & Urgench & Apr 08 \\
\hline 7 & $\begin{array}{l}\text { Validation of } \\
\text { research results }\end{array}$ & $\begin{array}{l}\text { members of fishery } \\
\text { community, women }\end{array}$ & Karakalpakstan & Apr 08 \\
\hline 8 & $\begin{array}{l}\text { Validation of } \\
\text { research results }\end{array}$ & $\begin{array}{l}\text { members of fishery } \\
\text { community, women }\end{array}$ & Karakalpakstan & Apr 08 \\
\hline 9 & $\begin{array}{l}\text { RPG - water } \\
\text { allocation }\end{array}$ & $\begin{array}{l}\text { members of water user } \\
\text { association, women }\end{array}$ & Urgench & Apr 08 \\
\hline 10 & $\begin{array}{ll}\text { RPG - water } \\
\text { allocation }\end{array}$ & $\begin{array}{l}\text { members of water user } \\
\text { association, women }\end{array}$ & Urgench & Apr 08 \\
\hline 11 & $\begin{array}{l}\text { RPG - fisheries } \\
\text { management }\end{array}$ & $\begin{array}{l}\text { members of fishery } \\
\text { community, women }\end{array}$ & Karakalpakstan & Apr 08 \\
\hline 12 & $\begin{array}{l}\text { RPG - fisheries } \\
\text { management }\end{array}$ & $\begin{array}{l}\text { members of fishery } \\
\text { community, women }\end{array}$ & Karakalpakstan & Apr 08 \\
\hline 13 & $\begin{array}{l}\text { participative } \\
\text { monitoring } \\
\text { system - soil } \\
\text { salinity }\end{array}$ & $\begin{array}{l}\text { representatives of } \\
\text { monitoring agency, monitors }\end{array}$ & Urgench & Apr 08 \\
\hline 14 & $\begin{array}{l}\text { participative } \\
\text { monitoring } \\
\text { system - wetlands }\end{array}$ & $\begin{array}{l}\text { representatives of fisheries } \\
\text { communities, scientists }\end{array}$ & Nukus & Apr 08 \\
\hline 15 & $\begin{array}{lr}\text { AM } & \text { measures } \\
\text { and results } \\
\text { evaluation }\end{array}$ & $\begin{array}{l}\text { relevant stakeholders from } \\
\text { administration, research, } \\
\text { NGO at national level }\end{array}$ & Tashkent & Apr 08 \\
\hline 16 & $\begin{array}{lr}\text { AM measures } \\
\text { and results } \\
\text { evaluation }\end{array}$ & $\begin{array}{l}\text { relevant stakeholders from } \\
\text { administration, research, } \\
\text { NGO at regional level }\end{array}$ & Urgench & Apr 08 \\
\hline 17 & $\begin{array}{lr}\text { AM } & \text { measures } \\
\text { and } & \text { results } \\
\text { evaluation } & \end{array}$ & $\begin{array}{l}\text { relevant stakeholders from } \\
\text { administration, research, } \\
\text { NGO at local level }\end{array}$ & Nukus & Apr 08 \\
\hline
\end{tabular}


Table A.3 Evaluation framework (with questions) adapted from Rowe and Frewer

\begin{tabular}{|c|c|c|c|c|c|c|c|}
\hline & $\begin{array}{l}\text { Assessment of } \\
\text { institutional barriers } \\
\text { for change }\end{array}$ & $\begin{array}{l}\text { Expert workshop } \\
\text { on environmental } \\
\text { flows }\end{array}$ & $\begin{array}{l}\text { Community based } \\
\text { research on social } \\
\text { aspects (FDGs) }\end{array}$ & $\begin{array}{l}\text { Community based } \\
\text { research- } \\
\text { validation }\end{array}$ & $\begin{array}{l}\text { Community based } \\
\text { research-Gaming } \\
\text { sessions }\end{array}$ & $\begin{array}{l}\text { Participative design of } \\
\text { monitoring system }\end{array}$ & $\begin{array}{l}\text { Participative evaluation } \\
\text { of project findings }\end{array}$ \\
\hline \multicolumn{8}{|c|}{ Acceptance criteria $^{1}$} \\
\hline Criterion of Representat & eness & & & & & & \\
\hline $\begin{array}{l}\text { Is this criterion } \\
\text { important for the } \\
\text { method? }\end{array}$ & Yes & Yes & No & Yes & No & Yes & Yes \\
\hline $\begin{array}{l}\text { Were all relevant } \\
\text { stakeholders invited? } \\
(\mathbf{y e s}=\mathbf{1}, \mathbf{n o}=\mathbf{0})\end{array}$ & 1 & $\mathbf{1}$ & 1 & 1 & 1 & 1 & 1 \\
\hline $\begin{array}{l}\text { Did all invited } \\
\text { participants show up? } \\
(\mathbf{y e s}=\mathbf{1}, \mathbf{n o}=\mathbf{0})\end{array}$ & $\mathbf{0}$ & $\mathbf{0}$ & 1 & $\mathbf{0}$ & $\mathbf{0}$ & 1 & $\mathbf{0}$ \\
\hline $\begin{array}{l}\text { Did these participants } \\
\text { represent their role in the } \\
\text { organisation? (yes=1, } \\
\text { no=0) }\end{array}$ & 1 & 1 & 1 & 1 & 1 & 1 & 1 \\
\hline $\begin{array}{l}\text { Did participants give } \\
\text { their own opinion? } \\
\text { (yes=1, no=0) }\end{array}$ & 1 & $\mathbf{0}$ & 1 & 1 & 1 & 1 & $\mathbf{0}$ \\
\hline $\begin{array}{l}\text { Was each participant } \\
\text { equally involved? } \\
\text { (yes }=\mathbf{1}, \mathbf{n o}=\mathbf{0} \text { ) }\end{array}$ & $\mathbf{0}$ & 1 & 1 & 1 & 1 & 1 & 1 \\
\hline Total & $3=60 \%$ mod. & $3=60 \%$ mod. & $5=100 \%$ high & $4=80 \%$ high & $4=80 \%$ high & $5=100 \%$ high & $3=60 \%$ moderate \\
\hline
\end{tabular}

${ }^{1}$ The total weighting of each criterion was determined by adding the given scores, $<33 \%=$ low, $34 \%-66 \%=$ moderate and $>67 \%=$ high 


\begin{tabular}{|c|c|c|c|c|c|c|c|}
\hline & $\begin{array}{l}\text { Assessment of } \\
\text { institutional barriers } \\
\text { for change }\end{array}$ & $\begin{array}{l}\text { Expert workshop } \\
\text { on environmental } \\
\text { flows }\end{array}$ & $\begin{array}{l}\text { Community based } \\
\text { research on social } \\
\text { aspects (FDGs) }\end{array}$ & $\begin{array}{l}\text { Community based } \\
\text { research- } \\
\text { validation }\end{array}$ & $\begin{array}{l}\text { Community based } \\
\text { research-Gaming } \\
\text { sessions }\end{array}$ & $\begin{array}{l}\text { Participative design of } \\
\text { monitoring system }\end{array}$ & $\begin{array}{l}\text { Participative evaluation } \\
\text { of project findings }\end{array}$ \\
\hline \multicolumn{8}{|l|}{ Acceptance criteria } \\
\hline \multicolumn{8}{|l|}{ Criterion of independence } \\
\hline $\begin{array}{l}\text { Is this criterion } \\
\text { important for the } \\
\text { method? }\end{array}$ & Yes & No & Yes & Yes & Yes & Yes & Yes \\
\hline $\begin{array}{l}\text { Did the facilitators } \\
\text { influence the responses } \\
\text { from the stakeholders? } \\
(\mathbf{n o = 1}, \mathbf{y e s}=\mathbf{0})\end{array}$ & $\mathbf{0}$ & $\mathbf{0}$ & $\mathbf{0}$ & $\mathbf{0}$ & $\mathbf{0}$ & 1 & $\mathbf{0}$ \\
\hline $\begin{array}{l}\text { Did you judge the } \\
\text { responses being made to } \\
\text { satisfy the researchers? } \\
\text { (Instead of reflecting } \\
\text { reality)?(no=1, yes=0) }\end{array}$ & 1 & 1 & $\mathbf{0}$ & 1 & $\mathbf{0}$ & 1 & 1 \\
\hline $\begin{array}{l}\text { Were there officials } \\
\text { present as observers? } \\
\text { (no=1, yes=0) }\end{array}$ & $\mathbf{0}$ & 1 & $\mathbf{0}$ & 1 & $\mathbf{0}$ & 1 & 1 \\
\hline $\begin{array}{l}\text { Was there a strong } \\
\text { hierarchy among the } \\
\text { participants present? } \\
(\mathbf{n o = 1 , y e s = 0 )}\end{array}$ & 1 & 1 & 1 & 1 & 1 & 1 & 1 \\
\hline $\begin{array}{l}\text { Were participants } \\
\text { holding back their } \\
\text { opinion (disinterested or } \\
\text { kept silence? (no=1, } \\
\text { yes=0) }\end{array}$ & 1 & 1 & $\mathbf{0}$ & 1 & 1 & 1 & 1 \\
\hline Total & $3=60 \%$ mod. & 4=80\% high & $1=20 \%$ low & $4=80 \%$ high & $2=40 \%$ mod. & $5=100 \%$ high & $5=100 \%$ high \\
\hline
\end{tabular}




\begin{tabular}{|c|c|c|c|c|c|c|c|}
\hline & $\begin{array}{l}\text { Assessment of } \\
\text { institutional barriers } \\
\text { for change }\end{array}$ & $\begin{array}{l}\text { Expert workshop } \\
\text { on environmental } \\
\text { flows }\end{array}$ & $\begin{array}{l}\text { Community based } \\
\text { research on social } \\
\text { aspects (FDGs) }\end{array}$ & $\begin{array}{l}\text { Community based } \\
\text { research- } \\
\text { validation }\end{array}$ & $\begin{array}{l}\text { Community based } \\
\text { research-Gaming } \\
\text { sessions }\end{array}$ & $\begin{array}{l}\text { Participative design of } \\
\text { monitoring system }\end{array}$ & $\begin{array}{l}\text { Participative evaluation } \\
\text { of project findings }\end{array}$ \\
\hline \multicolumn{8}{|l|}{ Acceptance criteria } \\
\hline \multicolumn{8}{|c|}{ Criterion of early involvement } \\
\hline $\begin{array}{l}\text { Is this } \begin{array}{r}\text { criterion } \\
\text { important for the } \\
\text { method? }\end{array}\end{array}$ & Yes & Yes & No & Yes & Yes & Yes & Yes \\
\hline $\begin{array}{l}\text { Were participants } \\
\text { involved in previous } \\
\text { activities of the NeWater } \\
\text { project? } \\
(\mathbf{y e s = 1 , n o = 0 )}\end{array}$ & 1 & 1 & $\mathbf{0}$ & 1 & 1 & 1 & 1 \\
\hline $\begin{array}{l}\text { How often? } \\
\text { (repetitively=1; } \quad \text { only } \\
\text { once=0) }\end{array}$ & 1 & 1 & 1 & 1 & 1 & n.A. & 1 \\
\hline $\begin{array}{l}\text { Where they aware of the } \\
\text { goals and activities of } \\
\text { NeWater? } \\
(\text { yes=1, no=0) }\end{array}$ & 1 & 1 & 1 & 1 & 1 & 1 & 1 \\
\hline \multicolumn{8}{|c|}{ 1000 bi b } \\
\hline & $3=100 \%$ high & $3=100 \%$ high & $2=67 \%$ high & $3=100 \%$ high & $3=100 \%$ high & $2=67 \%$ high & $3=100 \%$ high \\
\hline
\end{tabular}




\begin{tabular}{|c|c|c|c|c|c|c|c|}
\hline & $\begin{array}{l}\text { Assessment of } \\
\text { institutional barriers } \\
\text { for change }\end{array}$ & $\begin{array}{l}\text { Expert workshop } \\
\text { on environmental } \\
\text { flows }\end{array}$ & $\begin{array}{l}\text { Community based } \\
\text { research on social } \\
\text { aspects (FDGs) }\end{array}$ & $\begin{array}{l}\text { Community based } \\
\text { research- } \\
\text { validation }\end{array}$ & $\begin{array}{l}\text { Community based } \\
\text { research-Gaming } \\
\text { sessions }\end{array}$ & $\begin{array}{l}\text { Participative design of } \\
\text { monitoring system }\end{array}$ & $\begin{array}{l}\text { Participative evaluation } \\
\text { of project findings }\end{array}$ \\
\hline \multicolumn{8}{|l|}{ Acceptance criteria } \\
\hline \multicolumn{8}{|l|}{ Criterion of transparency } \\
\hline $\begin{array}{l}\text { Is this criterion } \\
\text { important for the } \\
\text { method? }\end{array}$ & Yes & Yes & Yes & Yes & Yes & Yes & Yes \\
\hline $\begin{array}{l}\text { Do participants know } \\
\text { what will happen with } \\
\text { the gathered data? } \\
(\mathbf{y e s}=\mathbf{1}, \mathbf{n o = 0})\end{array}$ & 1 & 1 & 1 & $\mathbf{0}$ & 1 & 1 & 1 \\
\hline $\begin{array}{l}\text { Do they participate in the } \\
\text { evaluation of the data? } \\
(\mathbf{y e s}=\mathbf{1}, \mathbf{n o}=\mathbf{0})\end{array}$ & 1 & $\mathbf{0}$ & N.A & 1 & $\mathbf{0}$ & 1 & 1 \\
\hline $\begin{array}{l}\text { Does the activity help the } \\
\text { participants to understand } \\
\text { how the information will } \\
\text { be processed/analyzed? } \\
(\mathbf{y e s}=\mathbf{1}, \mathbf{n o}=\mathbf{0})\end{array}$ & 1 & 1 & $\mathbf{0}$ & 1 & $\mathbf{0}$ & 1 & 1 \\
\hline \multicolumn{8}{|l|}{ Total } \\
\hline & $3=100 \%$ high & $2=67 \%$ high & $1=33 \%$ low & $2=67 \%$ high & $1=33 \%$ low & $3=100 \%$ high & $3=100 \%$ high \\
\hline
\end{tabular}




\begin{tabular}{|c|c|c|c|c|c|c|c|}
\hline & $\begin{array}{l}\text { Assessment of } \\
\text { institutional barriers } \\
\text { for change }\end{array}$ & $\begin{array}{l}\text { Expert workshop } \\
\text { on environmental } \\
\text { flows }\end{array}$ & $\begin{array}{l}\text { Community based } \\
\text { research on social } \\
\text { aspects (FDGs) }\end{array}$ & $\begin{array}{l}\text { Community based } \\
\text { research- } \\
\text { validation }\end{array}$ & $\begin{array}{l}\text { Community based } \\
\text { research-Gaming } \\
\text { sessions }\end{array}$ & $\begin{array}{l}\text { Participative design of } \\
\text { monitoring system }\end{array}$ & $\begin{array}{l}\text { Participative evaluation } \\
\text { of project findings }\end{array}$ \\
\hline \multicolumn{8}{|c|}{ Process criteria } \\
\hline \multicolumn{8}{|c|}{ Criterion of resource accessibility } \\
\hline $\begin{array}{l}\text { Is this criterion } \\
\text { important for the } \\
\text { method? }\end{array}$ & Yes & Yes & Yes & Yes & Yes & Yes & Yes \\
\hline $\begin{array}{l}\text { Was the facilitator } \\
\text { external to the NeWater } \\
\text { team? }(\mathbf{n o = 1}, \mathbf{y e s}=\mathbf{0})\end{array}$ & 1 & 1 & 1 & 1 & 1 & 1 & $\mathbf{0}$ \\
\hline $\begin{array}{l}\text { Was the language barrier } \\
\text { a big issue making the } \\
\text { application of the method } \\
\text { difficult? (no=1, yes=0) }\end{array}$ & 1 & 1 & 0 & $\mathbf{0}$ & $\mathbf{0}$ & 1 & 1 \\
\hline $\begin{array}{l}\text { Did participants know a } \\
\text { lot beforehand about the } \\
\text { activity? (yes }=\mathbf{1}, \mathbf{n o}=\mathbf{0})\end{array}$ & $\mathbf{0}$ & 1 & $\mathbf{0}$ & 1 & $\mathbf{0}$ & $\mathbf{0}$ & $\mathbf{0}$ \\
\hline $\begin{array}{l}\text { Was the time for the } \\
\text { activity restricting? } \\
\text { (no=1, yes=0) }\end{array}$ & $\mathbf{0}$ & $\mathbf{0}$ & 1 & 0 & $\mathbf{0}$ & 1 & 0 \\
\hline $\begin{array}{l}\text { Is there a high technical } \\
\text { resources demand for } \\
\text { data collection? (no=1, } \\
\text { yes=0) }\end{array}$ & 1 & 1 & 1 & 1 & 1 & 1 & 1 \\
\hline Total & $3=60 \%$ mod. & $4=80 \%$ high & $2=40 \% \bmod$ & $3=60 \%$ mod. & $2=40 \% \bmod$ & $4=80 \%$ high & $2=40 \% \bmod$ \\
\hline
\end{tabular}




\begin{tabular}{|c|c|c|c|c|c|c|c|}
\hline & $\begin{array}{c}\text { Assessment of } \\
\text { institutional barriers } \\
\text { for change }\end{array}$ & $\begin{array}{l}\text { Expert workshop } \\
\text { on environmental } \\
\text { flows }\end{array}$ & $\begin{array}{l}\text { Community based } \\
\text { research on social } \\
\text { aspects (FDGs) }\end{array}$ & $\begin{array}{l}\text { Community based } \\
\text { research- } \\
\text { validation }\end{array}$ & $\begin{array}{c}\text { Community based } \\
\text { research-Gaming } \\
\text { sessions }\end{array}$ & $\begin{array}{c}\text { Participative design of } \\
\text { monitoring system }\end{array}$ & $\begin{array}{l}\text { Participative evaluation } \\
\text { of project findings }\end{array}$ \\
\hline \multicolumn{8}{|l|}{ Process criteria } \\
\hline \multicolumn{8}{|l|}{ Criterion of task definition } \\
\hline $\begin{array}{l}\text { Is this criterion } \\
\text { important for the } \\
\text { method? }\end{array}$ & Yes & Yes & Yes & Yes & Yes & No & Yes \\
\hline 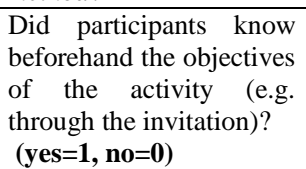 & 1 & $\mathbf{1}$ & $\mathbf{0}$ & 1 & 1 & 1 & 1 \\
\hline $\begin{array}{lr}\text { Did } & \text { participants } \\
\text { understand } & \text { the } \\
\text { connection } & \text { to the } \\
\text { previous } & \text { NeWater } \\
\text { activities? } & \\
(\text { (yes=1, no=0) } & \end{array}$ & $\mathbf{0}$ & $\mathbf{0}$ & $\mathbf{0}$ & 1 & 1 & 1 & $\mathbf{0}$ \\
\hline $\begin{array}{l}\text { Was there a Pre-test of } \\
\text { the method application? } \\
\text { (yes=1, no=0) }\end{array}$ & 1 & 1 & 1 & $\mathbf{0}$ & 1 & $\mathbf{0}$ & 1 \\
\hline $\begin{array}{l}\text { Did the participants } \\
\text { understand clearly the } \\
\text { method in the beginning } \\
\text { of the activity? } \\
(\text { yes }=\mathbf{1}, \mathbf{n o}=\mathbf{0} \text { ) }\end{array}$ & 1 & 1 & 1 & 1 & 1 & 1 & 1 \\
\hline $\begin{array}{l}\text { Did the participants have } \\
\text { a clear focus of task } \\
\text { throughout the whole } \\
\text { activity? } \\
(\text { (yes=1, no=0) }\end{array}$ & 1 & 1 & $\mathbf{0}$ & 1 & $\mathbf{0}$ & 1 & $\mathbf{0}$ \\
\hline Total & $4=80 \%$ high & $4=80 \%$ high & $2=40 \%$ low & $4=80 \%$ high & $4=80 \%$ high & 4=80\% high & $3=60 \%$ mod. \\
\hline
\end{tabular}




\begin{tabular}{|c|c|c|c|c|c|c|c|}
\hline & $\begin{array}{c}\text { Assessment of } \\
\text { institutional barriers } \\
\text { for change }\end{array}$ & $\begin{array}{l}\text { Expert workshop } \\
\text { on environmental } \\
\text { flows }\end{array}$ & $\begin{array}{l}\text { Community based } \\
\text { research on social } \\
\text { aspects (FDGs) }\end{array}$ & $\begin{array}{l}\text { Community based } \\
\text { research- } \\
\text { validation }\end{array}$ & $\begin{array}{c}\text { Community based } \\
\text { research-Gaming } \\
\text { sessions }\end{array}$ & $\begin{array}{l}\text { Participative design of } \\
\text { monitoring system }\end{array}$ & $\begin{array}{c}\text { Participative evaluation } \\
\text { of project findings }\end{array}$ \\
\hline \multicolumn{8}{|c|}{ Process criteria } \\
\hline \multicolumn{8}{|c|}{ Criterion of system understanding } \\
\hline $\begin{array}{l}\text { Is this criterion } \\
\text { important for the } \\
\text { method? }\end{array}$ & Yes & Yes & Yes & Yes & Yes & Yes & Yes \\
\hline $\begin{array}{l}\text { Did this activity increase } \\
\text { the system } \\
\text { understanding? } \\
(\mathbf{y e s}=\mathbf{1}, \mathbf{n o}=\mathbf{0})\end{array}$ & 1 & 1 & 1 & 1 & 1 & $\mathbf{0}$ & 1 \\
\hline $\begin{array}{l}\text { Was the focus of the } \\
\text { activity towards } \\
\text { improved integrated } \\
\text { system understanding } \\
\text { and development of } \\
\text { measures and strategies? } \\
(\text { yes }=\mathbf{1}, \mathbf{n} \mathbf{0}=\mathbf{0})\end{array}$ & 1 & 1 & 1 & 1 & 1 & 1 & 1 \\
\hline Total & $2=100 \%$ high & $2=100 \%$ high & $2=100 \%$ high & $2=100 \%$ high & $2=100 \%$ high & $1=50 \%$ moderate & $2=100 \%$ high \\
\hline
\end{tabular}




\begin{tabular}{|c|c|c|c|c|c|c|c|}
\hline & $\begin{array}{c}\text { Assessment of } \\
\text { institutional barriers } \\
\text { for change }\end{array}$ & $\begin{array}{c}\text { Expert workshop } \\
\text { on environmental } \\
\text { flows }\end{array}$ & $\begin{array}{l}\text { Community based } \\
\text { research on social } \\
\text { aspects (FDGs) }\end{array}$ & $\begin{array}{l}\text { Community based } \\
\text { research- } \\
\text { validation }\end{array}$ & $\begin{array}{c}\text { Community based } \\
\text { research-Gaming } \\
\text { sessions }\end{array}$ & $\begin{array}{l}\text { Participative design of } \\
\text { monitoring system }\end{array}$ & $\begin{array}{l}\text { Participative evaluation } \\
\text { of project findings }\end{array}$ \\
\hline \multicolumn{8}{|c|}{ Process criteria } \\
\hline \multicolumn{8}{|c|}{ Criterion of cost-effectiveness } \\
\hline 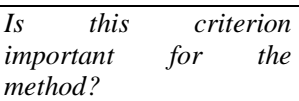 & Yes & Yes & Yes & Yes & Yes & Yes & Yes \\
\hline $\begin{array}{l}\text { Is the operationalization } \\
\text { of the activity easy? } \\
\text { (yes }=\mathbf{1}, \mathbf{n o}=\mathbf{0} \text { ) }\end{array}$ & 1 & 1 & 1 & 1 & 1 & 1 & 1 \\
\hline $\begin{array}{l}\text { Does the activity require } \\
\text { much preparation in } \\
\text { advance? } \\
(\text { no= } \mathbf{1} \text {, yes }=\mathbf{0})\end{array}$ & 1 & 1 & $\mathbf{0}$ & $\mathbf{0}$ & $\mathbf{0}$ & 1 & 1 \\
\hline $\begin{array}{l}\text { Did the participants } \\
\text { consider it worthwhile } \\
\text { engaging into the } \\
\text { activity? } \\
(\text { (yes=1, no=0) }\end{array}$ & 1 & 1 & 1 & 1 & 1 & 1 & 1 \\
\hline $\begin{array}{l}\text { Did the activity reach its } \\
\text { goal? } \\
(\mathbf{y e s}=\mathbf{1}, \mathbf{n o}=\mathbf{0})\end{array}$ & 1 & 1 & 1 & 1 & 1 & 1 & 1 \\
\hline Total & $4=100 \%$ high & $4=100 \%$ high & $3=75 \%$ high & $3=75 \%$ high & $3=75 \%$ high & $4=100 \%$ high & $4=100 \%$ high \\
\hline
\end{tabular}

